\section{URANIUM ENRICHMENT}

MARTIN MARUETTA

\section{ASSESSMENT AND INTERPRETATION \\ OF CROSS- AND DOWN-HOLE SEISMOGRAMS AT THE PADUCAH GASEOUS DIFFUSION PLANT}

W. P. Staub

J. C. Wang

R. J. Selfridge

September 1991 


\section{DISCLAIMER}

This report was prepared as an account of work sponsored by an agency of the United States Government. Neither the United States Government nor any agency thereof, nor any of their employees, makes any warranty, express or implied, or assumes any legal liability or responsibility for the accuracy, completeness, or usefulness of any information, apparatus, product, or process disclosed, or represents that its use would not infringe privately owned rights. Reference herein to any specific commercial product, process, or service by trade name, trademark, manufacturer, or otherwise, does not necessarily constitute or imply its endorsement, recommendation, or favoring by the United States Government or any agency thereof. The views and opinions of authors expressed herein do not necessarily state or reflect those of the United States Government or any agency thereof. 
K/GDP/SAR- -9

DE92 001841

GASEOUS DIFFUSION PLANT

SAFETY ANALYSIS REPORT UPGRADE PROGRAM

\section{ASSESSMENT AND INTERPRETATION \\ OF CROSS- AND DOWN-HOLE SEISMOGRAMS \\ AT THE PADACUH GASEOUS DIFFUSION PLANT}

W. P. Staub

J. C. Wang

Oak Ridge National Laboratory

R. J. Selfridge

Automated Sciences Group

Date Published-September 1991

\section{MARTIN MARIETTA ENERGY SYSTEMS, INC.}

managing the

Oak Ridge K-25 Site

Oak Ridge Y-12 Plant

Oak Ridge National Laboratory Paducah Gaseous Diffusion Plant under contract DE-AC05-84OR21400

and the

Portsmouth Gaseous Diffusion Plant under contract DE-AC05-76OR00001

for the

U.S. DEPARTMENT OF ENERGY 


\section{CONTENTS}

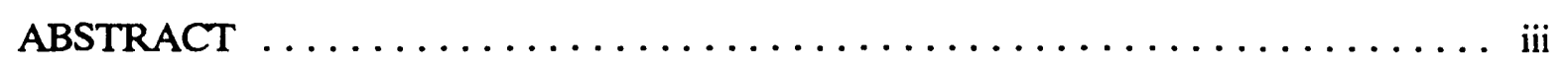

1. INTRODUCTION $\ldots \ldots \ldots \ldots \ldots \ldots \ldots \ldots \ldots \ldots \ldots \ldots \ldots \ldots \ldots \ldots \ldots$

2. CROSS-HOLE SEISMOGRAMS $\ldots \ldots \ldots \ldots \ldots \ldots \ldots \ldots \ldots \ldots \ldots \ldots \ldots \ldots \ldots$

2.1 S-WAVES $\ldots \ldots \ldots \ldots \ldots \ldots \ldots \ldots \ldots \ldots \ldots \ldots \ldots \ldots \ldots \ldots \ldots \ldots \ldots \ldots, 2$

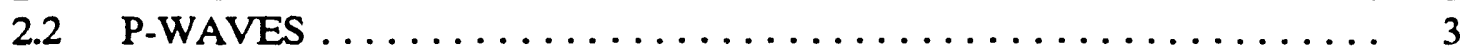

3. DOWN-HOLE SEISMOGRAMS $\ldots \ldots \ldots \ldots \ldots \ldots \ldots \ldots \ldots \ldots \ldots$

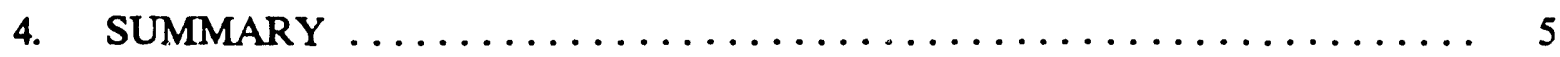

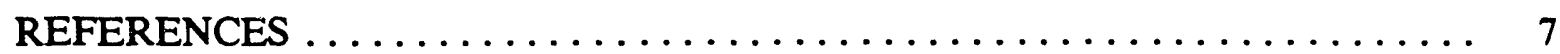

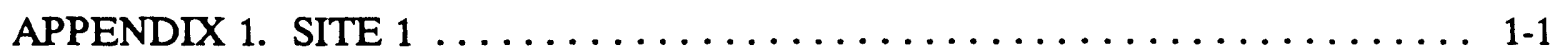

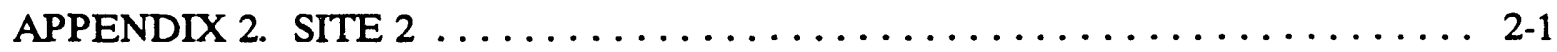

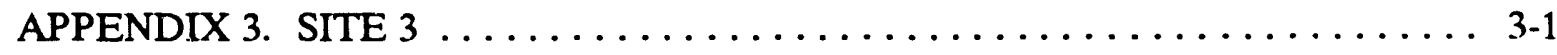

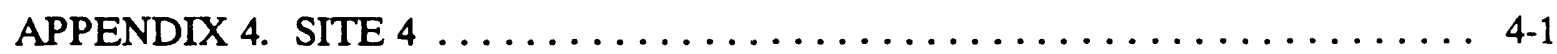

APPENDIX 5. SUMMARY OF S- AND P-WAVE VELOCITY ESTIMATES $\ldots . .5$ 5-1

APPENDIX 6. SOIL COLUMNS AND SITE LOCATION MAP $\ldots \ldots \ldots \ldots 6-1$ 


\begin{abstract}
This paper is an assessment and interpretation of cross-and down-hole seismograms recorded by Automiated Sciences Group (ASG), 1991, at four sites in the vicinity of the Paducah Gaseous Diffusion Plant (PGDP). Arrival times of shear (S-) and compressional (P-) waves are recorded on these seismograms in milliseconds. Together with known distances between energy sources and seismometers lowered into boreholes, these arrival times are used to calculate $S$ - and $\mathbf{P}$-wave velocities in unconsolidated soils and sediments that overlie bedrock approximately $320 \mathrm{ft}$ beneath PGDP.

Tabulated S- and P-wave velocity estimates at Sites 1 through 4 are presented in Appendices 1 through 4, respectively. Comparisons of velocity estimates among the four sites are tabulated in Appendix 5. S- and P-wave velocity estimates to be used in four soil columns (unconsolidated soils from the surface to bedrock) are also in Appendix 5.

The soil columns are modified after an earlier draft by ERC Environmental and Energy Services Company (ERCE), 1990. In addition to $S$ - and $\mathrm{P}$-wave velocity estimates from this paper, the soil columns contain ERCE's lithologic and other geotechnical data for unconsolidated soils and sediments from the surface to bedrock. Soil columns for Sites 1 through 4 and a site location map are in Plates 1 through 5 of Appendix 6.

The velocities in the four soil columns are input parameters for the SHAKE computer program, a nationally recognized computer model that simulates ground response of unconsolidated materials to earthquake generated seismic waves (Schnabel et al. 1974). The results of the SHAKE simulation are combined with predicted ground responses on rock foundations (caused by a given design earthquake) to predict ground responses of facilities with foundations placed on unconsolidated materials.
\end{abstract}




\section{INTRODUCTION}

Oak Ridge National Laboratory staff were asked to provide an assessment and interpretation of ASG's (1991) data package, "Seismic Wave Study of Subsurface Conditions in the Vicinity of the Paducah Gaseous Diffusion Plant." As a byproduct of this assessment an independent quality assurance of S- and P-wave velocity data presented in ASG's data package was also obtained.

ASG provided cross-hole seismic data in shallow holes (up to $135 \mathrm{ft}$ deep) at each of four sites and down-hole seismic data in deep holes (300 and $350 \mathrm{ft}$ deep) at Sites 3 and 4. A limited amount of shallow down-hole data are available for Site 2, and no down-hole data are available for Site 1. Cross- and down-hole data are discussed separately in the following sections. Tables and figures for cross- and down-hoie data are presented in Appendices 1 through 4 for Sites 1 through 4, respectively. Appendix 5 contains a summary of seismic information to be used as input for Sites 1 through 4 revised soil columns as presented by ERCE's (1990) draft document, "Recommended Soil Columns for Use in Amplification Studies, Paducah Gaseous Diffusion Plant." Soil columns for Sites 1-4 and a site location map are in Plates 1 through 5 of Appendix 6.

Formats for tables and figures in Appendices 1 through 3 are consistent throughout this report. The format in Appendix 4 differs because seismic cross-hole velocities at Site 4 were only measured in one direction, rather than in both forwara and reverse directions.

Tables 1 and 2 of Appendices 1 through 3 present forward and reverse measured S-wave velocities (as measured by the cross-hole method) at 5 - $\mathrm{ft}$-depth intervals from $5 \mathrm{ft}$ below the surface to depths ranging from 65 to $135 \mathrm{ft}$. Table 3 compares revised S-wave velocities as a function of depth measured in both forward and reverse directions and provides mean values and differences of these velocities. Table 4 provides information similar to that in Table 3 for measured cross-hole P-wave velocities. Table 5 (Appendix 3 only) lists measured down-hole S-wave velocities and calculated down-hole $\mathbf{P}$-wave velocities to bedrock for Site 3.

Tables 1 and 2 of Appendix 4 (Site 4) provide shallow measured cross-hole S- and $\mathrm{P}$-wave velocities, respectively. Table 3 presents a measured down-hole S-wave velocity and calculated down-hole P-wave velocities to bedrock for Sites 1, 2, and 4.

Five tables are provided in Appendix 5 (Summary). Table 1 lists mean value measured cross-hole S-wave velocity estimates at 5-ft intervals for shallow depths ranging up to $135 \mathrm{ft}$ for all four sites. Table 2 lists linear least-squares fit measured down-hole S-wave velocity estimates at selected intervals from a depth of $123 \mathrm{ft}$ to $334 \mathrm{ft}$, respectively, and calculated $\mathrm{P}$-wave velocities for the same intervals for all sites. Table 3 lists mean value measured crosshole $\mathrm{P}$-wave velocity estimates for Sites 1 through 3 and single valued measured $\mathrm{P}$-wave estimates for Site 4 . Tables 4 and 5 list $S$ - and P-wave velocity estimates, respectively, for inclusion in ASG's soil columns at all 4 sites. 


\section{CROSS-HOLE SEISMOGRAMS}

\section{S-WAVES}

The evaluation of ASG's original S-wave velocity estimates derived from cross-hole seismograms allows for three possible outcomes. Either (1) the interpretation of the seismogram is correct and the S-wave velocity need not be revised, (2) the interpretation is incorrect and the S-wave velocity must be revised, or (3) the seismogram is of such poor quality that the S-wave velocity must be rejected.

Tables 1 and 2 of Appendices 1 through 3 (Sites 1 through 3) present S-wave data. Table 2 presents seismic data recorded in the reverse direction from that of Table 1 . The first two columns provide depths and S-wave velocities in 5-ft increments from Appendix B of ASG's document (1991). The next two columns indicate whether the S-wave velocity in column 2 at a given depth in column 1 was rejected or revised. Subsequent columns constitute a checklist of reasons why the original data were rejected or revised. First arrivals were often weak or interfered by noise (for example, operating plant equipment at Site 2). Also, the identification of the arriving S-wave was often inconsistent, both between seismograms and within a given seismogram; that is, the polarity, sharpness, and character of the "first-arrival" S-waves differed. Finally, S-wave velocities measured from energy source to near receiver and from the reverse direction were inconsistent. The evaluation rejected most weak and noisy data and established consistency in identifying first arrivals.

Some S-wave velocity revisions are unrelated to the interpretation of seismograms. At Site 3, both $\mathrm{S}$ - and $\mathrm{P}$-wave velocities in forward and reverse directions between energy sources and near and far receivers were inconsistent even though the quality of seismograms was excellent (ASG 1991, Appendix B). These inconsistencies suggest that the distances between the energy source and receivers were calculated incorrectly (incorrect borehole deviation data). ASG recomputed the borehole deviations for all four sites. These changes produced slightly revised results for Sites 1 and 2 and changed the results at Site 3 significantly. S- and P-wave velocity estimates in forward and reverse directions are now consistent at Sites 1 through 3, and recalculated distances between energy sources and receivers are believed to be correct. At Site 4, S- and P-wave velocities were measured in only one direction. Therefore, only single valued estimates are available at Site 4 , and measured velocities are not known with the same degree of confidence as at Sites 1 through 3.

Table 3 presents revised S-wave velocities of Tables 1 and 2 side-by-side for comparison, mean values, and differences for forward and reverse recordings as a function of depth for Sites 1, 2, and 3 (Appendices 1 through 3). S-wave velocities are generally consistent throughout. S-wave velocities in the forward and reverse directions differ from a few tens-offeet per second to about $150 \mathrm{ft} / \mathrm{s}$. Figures 1.1, 2.1, and 3.1 are forward and reverse $\mathrm{S}$ - and P-wave velocities for Sites 1, 2, and 3 (Appendices 1 through 3), plotted side-by-side for comparison. Cross-hole P-wave velocities (discussed in greater detail in Sect. 2.2) in the forward and reverse directions differ from a few tens-of-feet per second to about $650 \mathrm{ft} / \mathrm{s}$, $1200 \mathrm{ft} / \mathrm{s}$, and $1800 \mathrm{ft} / \mathrm{s}$ for Sites 1 through 3, respectively. 


\subsection{P-WAVES}

Unlike S-wave energy arrivals, P-wave energy arrivals were identified in a consistent manner. This evaluation does not challenge the interpretation of seismograms with respect to $\mathrm{P}$-wave energy arrival times. However, in the original data package, calculated $\mathrm{P}$-wave velocities in the reverse direction (energy source at $\mathrm{Z11}$ ) were nearly twice as high as those in the forward direction (energy source at Z09) at Site 3. This suggests that the hole deviation corrections may have been in error. Hole deviation data were recalculated, and revised S- and P-wave velocities were determined for all sites. Discussion of the revised S-wave velocities is presented in Sect. 2.1.

Revised P-wave velocity estimates are presented in Table 4 of Appendices 1 through 3 (Sites 1 through 3) and in Table 2 of Appendix 4 (Site 4). Revised P-wave velocities in forward and reverse directions now compare favorably and are reasonable at Sites 1 through 3. However, few seismograms were recorded in the reverse direction at Site 4. 


\section{DOWN-HOLE SEISMOGRAMS}

Shallow down-hole seismograms were recorded at Site 2 and deep down-hole seismograms were recorded at Sites 3 and 4 . Since the purpose of the down-hole surveys is to obtain S- and P-wave velocities at depths below the bottom of the cross-hole survey holes, only the down-hole surveys at Sites 3 and 4 will be discussed further.

The original intention of the down-hole surveys was to determine interval velocities every $10 \mathrm{ft}$ to the bottom of each hole. Unfortunately, the signals were too weak to determine arrival times with the required degree of accuracy (ASG 1991, Appendix C).

Alternatively, down-hole S-wave velocities were determined by plotting arrival times as a function of depth and applying linear least-squares fits to data from the deep holes. The onset (first arrival) of S-wave energy could not be identified throughout the depth of the hole. Instead, later cycles of the arriving energy were selected for various depth intervals (care was taken to pick the same cycle for a given depth interval). Separate sets of linear least-squares fits were provided for each depth interval in the deep holes.

The quality of down-hole seismograms was too poor to provide reliable estimates of $P$-wave velocities. As an alternative, down-hole $P$-wave velocities were calculated by using the equation,

$$
0=\frac{\left[1-2\left(\frac{V_{s}}{V_{p}}\right)^{2}\right]}{\left[2-2\left(\frac{V_{s}}{V_{p}}\right)^{2}\right]},
$$

where

0 = Poisson's ratio,

$V_{s}=$ S-wave velocity,

$V_{p}=\mathrm{P}$-wave velocity.

Then, $V_{p}$ was calculated at appropriate depth intervals where $V_{s}$ is known. Most likely values of $\mathrm{P}$-wave velocities and upper and lower limit values are based on mean values of Poisson's ratio and one standard deviation values above and below the mean, respectively. Poisson's ratio is estimated from appropriate cross-hole seismograms where reliable $\mathrm{S}$ - and $\mathrm{P}$-wave velocity estimates are both available (Tables 3 and 4, Appendices 2 and 3).

Measured S-wave down-hole velocity estimates are presented in Tables 5 and 3 of Appendices 3 and 4 (Sites 3 and 4), respectively. Calculated P-wave down-hole velocity estimates are also presented in these tables. 


\section{SUMMARY}

Table 1 of Appendix 5 summarizes cross-hole S-wave velocity estimates where reliable data were available at all four sites. S-wave velocities are generally above $1200 \mathrm{ft} / \mathrm{s}$ below a depth of about $75 \mathrm{ft}$ and generally less than $1200 \mathrm{ft} / \mathrm{s}$ at shallower depths, except at Site 4.

The increase in S-wave velocity as a function of depth is believed to be related to differences in lithology, age, and increasing overburden pressure. All sites are underlain by marine sands and silts of Paleogene age. Marine sediments have relatively uniform lithologies relative to continental sediments. These Paleogene sediments are also relatively old compared to the overlying Holocene and Pleistocene sediments (several tens-of-miilions of years old compared to 10,000 to a few million years old). Their age and depth of burial combine to produce greater consolidation of Paleogene sediments relative to younger sediments at shallower depth. The modulus of rigidity increases (consequently, the S-wave velocity increases) as the degree of consolidation increases.

At shallower depths, shown in Table 1, S-wave velocities are generally greater than 1100 $\mathrm{ft} / \mathrm{s}$ at Sites 2 and 4 and generally less than $1100 \mathrm{ft} / \mathrm{s}$ at Sites 1 and 3. The relatively low S-wave velocities at shallow depth at Site 1 may be attributable to high moisture content in the Porters Creek Clay. The low S-wave velocities at shallow depth at Site 3 may be attributable to the presence of poorly consolidated Holocene sediments in relation to Pleistocene sediments at Sites 2 and 4.

Table 2 of Appendix 5 summarizes measured down-hole S-wave velocity estimates and calculated down-hole P-wave velocity estimates where reliable data were available from a depth of 123 to $334 \mathrm{ft}$ at Sites 3 and 4. The down-hole S-wave velocity at Site 3 ranges from 1155 to $1545 \mathrm{ft} / \mathrm{s}$, and the down-hole S-wave velocity is constant $(1550 \mathrm{ft} / \mathrm{s})$ at Site 4.

Table 2 of Appendix 5 also summarizes calculated down-hole P-wave velocities. At Site 3, down-hole P-wave velocities range from 5710 to $7635 \mathrm{ft} / \mathrm{s}$, and at Site 4 the $\mathrm{P}$-wave velocity is constant $(7605 \mathrm{ft} / \mathrm{s})$.

Table 3 of Appendix 5 summarizes cross-hole $P$-wave velocity estimates, where reliable data are available, at all four sites. There is wide variation in these results for Sites 2,3 , and 4. P-wave velocity estimates from 70 to $115 \mathrm{ft}$ are generally high (greater than $6000 \mathrm{ft} / \mathrm{s}$ ). $\mathrm{P}$-wave velocity estimates between 70 and $85 \mathrm{ft}$ at Site 4 are unusually high (greater than 7500 $\mathrm{ft} / \mathrm{s}$ ) for unconsolidated sediments. Rather uniform P-wave velocity estimates at Site 1 are believed to be attributable to a more uniform lithology in the marine Porters Creek Clay in contrast to the continental gravel, sand, and silt at the other sites.

Table 4 contains S-wave velocity estimates for use in the soil columns. At each site, cross-hole velocities from Tables 1 and 3 and down-hole velocities from Table 2 were used to compile information for the soil columns. Where S-wave velocity estimates vary by less than $100 \mathrm{ft} / \mathrm{s}$ throughout a given depth interval, that interval is considered to be one layer. Mean value velocity estimates are given for each layer in Table 4.

At Site 1, the mean value cross-hole S-wave velocity estimate is available only for the upper half of the Porters Creek Clay. This mean value velocity is extended downward 
through the soil column to the contact between the Porters Creek Clay and the underlying Clayton-McNairy strata. This is acceptable because the lithology of the Porters Creek Clay is relatively uniform. Also, no S-wave velocity estimates are availab'a at Site 1 for the Clayton-McNairy interval to the top of rock. Down-hole S-wave velocity estimates from the top of the Clayton-McNairy strata to the top of rock at Site 4 are transposed to Site 1 and extend from the Porters Creek-Clayton-McNairy contact to the top of rock [from $123 \mathrm{ft}$ below the surface to the top of rock (assumed to be at the same depth as at Site 4 [322 ft])]. Seismic characteristics of the Clayton-McNairy stratigraphic section beneath Site 1 are expected to be similar to that beneath Site 4. This site is much closer to Site 4 than to Site 3 , the only other site where deep down-hole seismic data are available. Sites 1 and 4 also have complete and nearly complete sections of Clayton-McNairy strata, respectively, whereas the top of the Clayton-McNairy section is eroded $10 \mathrm{ft}$ deeper at Site 3 and replaced by the regional aquifer.

At Site 2, mean value cross-hole S-wave velocity estimates are available all the way to the contact between the regional aquifer and the underlying Clayton-McNairy strata. Again, no S-wave velocity estimates are available at Site 2 for the Clayton-McNairy strata to the top of bedrock. From the bottom of the regional aquifer to the top of rock, down-hole S-wave velocity estimates from Site 4 are transposed to Site 2 and extended from the regional aquifer-Clayton-McNairy contact at $120 \mathrm{ft}$ below the surface to the top of rock [assumed to be at the same depth as at Site $4(322 \mathrm{ft})]$. Site 2 is also closer to Site 4 than Site 3 . Also, the Site 2 Clayton-McNairy section is nearly complete, like that of Site 4.

At Site 3, mean value cross-hole S-wave velocity estimates are available to about $20 \mathrm{ft}$ beneath the contact between the regional aquifer and the Clayton-McNairy strata (about 120 $\mathrm{ft}$ beneath the surface). From there, down-hole S-wave velocity estimates are available nearly to the top of rock (334 $\mathrm{ft}$ beneath the surface) at Site 3 .

At Site 4, single valued cross-hole S-wave velocity estimates are available to about 20 $\mathrm{ft}$ beneath the contact between the regional aquifer and the Clayton-McNairy strata. From there, down-hole S-wave velocity estimates are available nearly to the top of rock $(322 \mathrm{ft}$ beneath the surface) at Site 4 .

Table 5 contains P-wave velocity estimates for use in the soil columns. At each site, measured cross-hole velocities from Table 3 and calculated down-hole velocities from Table 2 were used to compile P-wave velocity data for the soil columns. Where P-wave velocity estimates vary by less than $500 \mathrm{ft} / \mathrm{s}$ througnout a given depth interval, that interval is considered to be one layer. Mean value $\mathrm{P}$-wave velocity estimates are given for each layer in Table 5.

At Sites 1 through 3 the same strategies used for compiling S-wave velocity data for the soil columns are also used for $\mathbf{P}$-wave velocity data. 


\section{REFERENCES}

ASG (Automated Sciences Group, Inc.). 1991. "Final Data Package, Geophysical Study of Subsurface Conditions in the Vicinity of the Paducah Gaseous Diffusion Plant." Oak Ridge, Tennessee.

ERCE (ERC Environmental and Energy Services Co., Inc.). 1990. Draft, "Recommended Soil Columns for Use in Amplification Studies, Paducah Gaseous Diffusion Plant." Knoxville, Tennessee.

Schnabel, P. B., Lysmer, J., and Seed, H. B. 1974. "SHAKE, a Computer Program for Earthquake Response Analysis of Horizontally Layered Sites: University of California, Berkeley." Report No. EERC 72-12. 
APPENDIX 1

SITE 1 


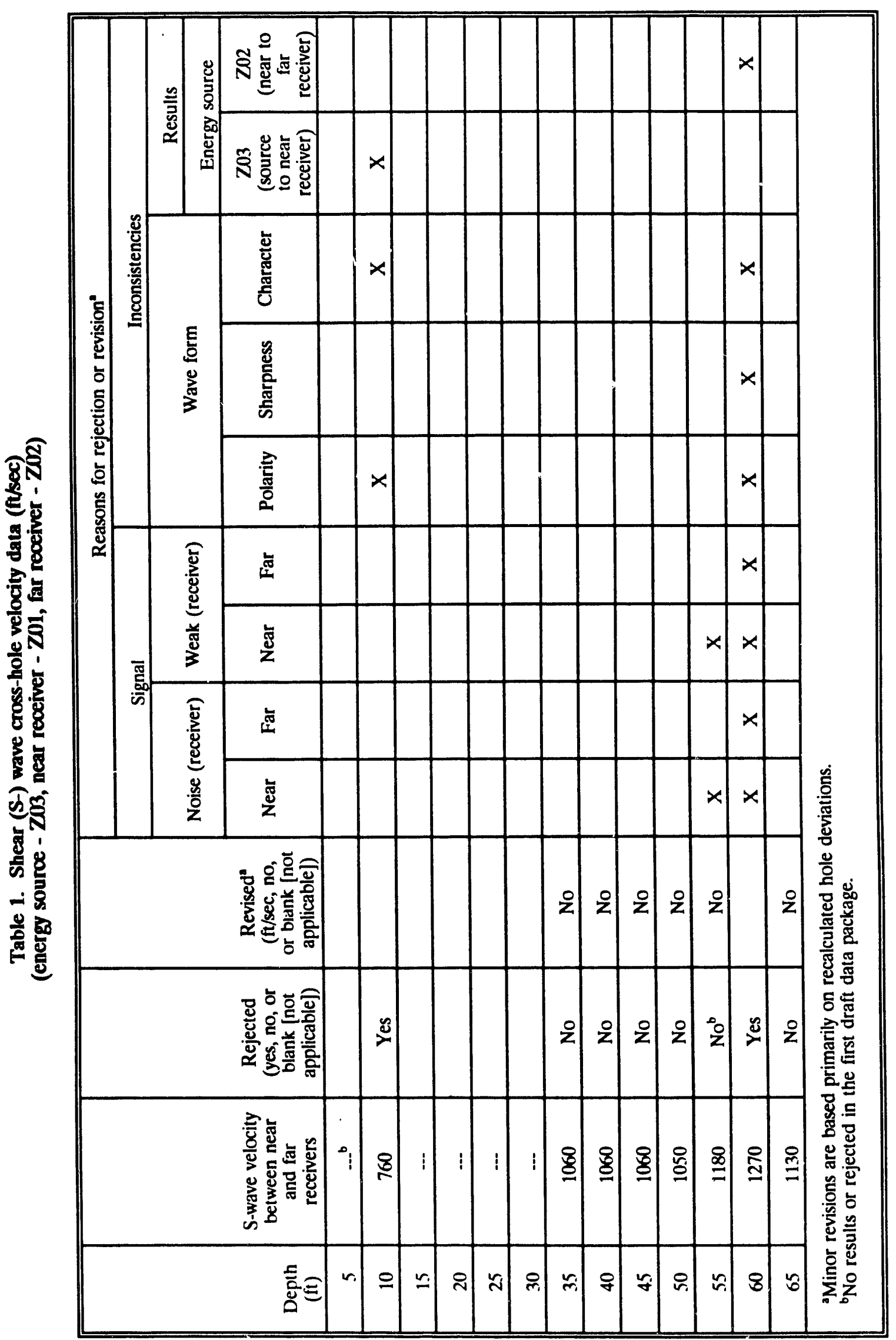




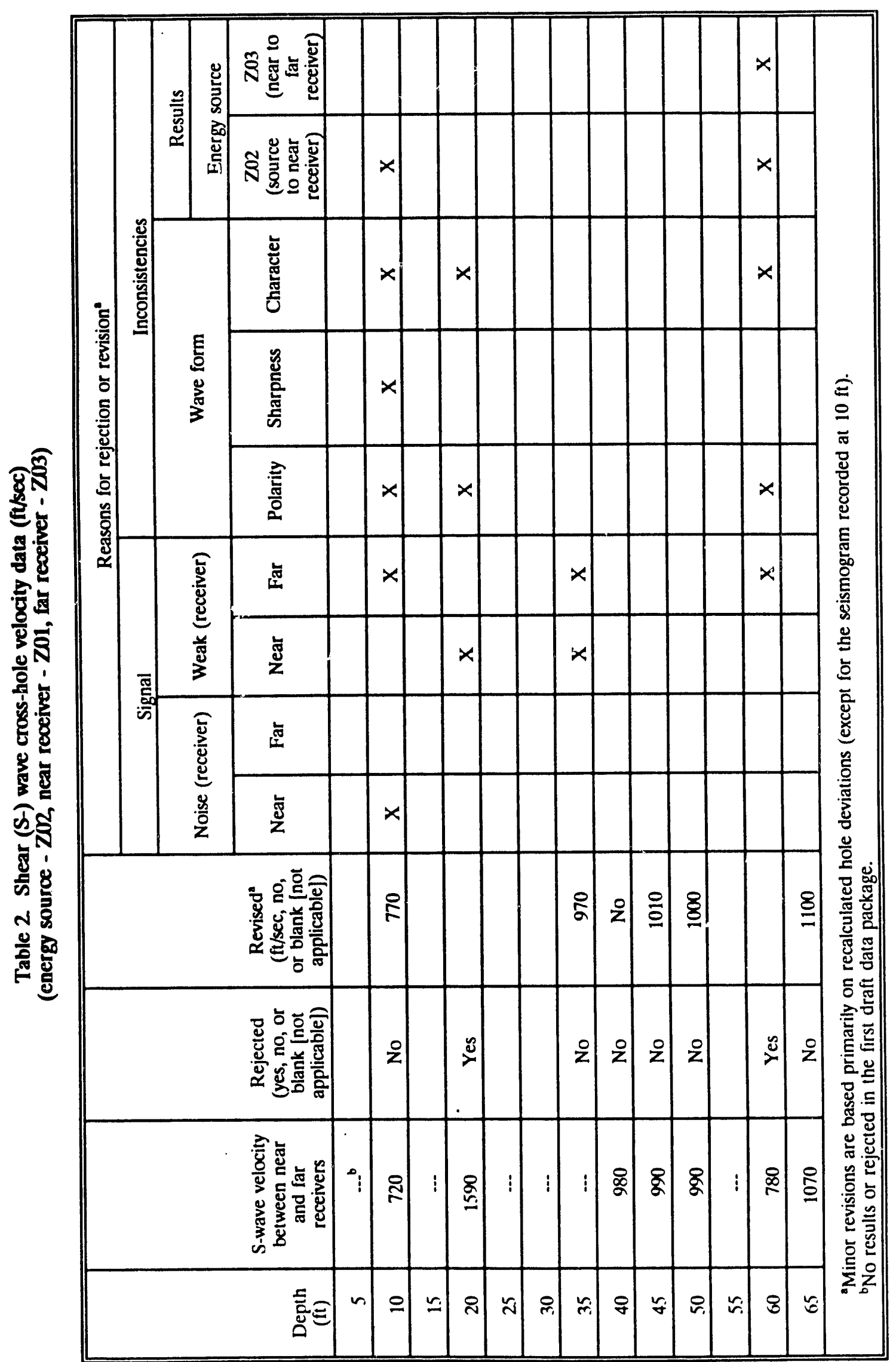


Table 3. Shear (S-) wave cross-hole velocity data [comparison of forward ( $\mathrm{ZO2}$ ) and reverse ( $\mathrm{Z03}$ ) direction results]

\begin{tabular}{||c|c|c|c|c||}
\hline \multirow{2}{*}{ Depth } & \multicolumn{3}{|c|}{ S-wave velocities (ft/sec) } \\
\cline { 2 - 4 } & \multicolumn{2}{|c|}{ Energy source } & \multirow{2}{*}{ Difference } & Mean \\
\cline { 2 - 5 } & Z02 & Z03 & $\ldots$ & $\ldots$ \\
\hline 10 & $\ldots$ & $\ldots$ & $\ldots$ & 770 \\
\hline 15 & 770 & $\ldots$ & $\ldots$ & $\ldots$ \\
\hline 20 & $\ldots$ & $\ldots$ & $\ldots$ & $\ldots$ \\
\hline 25 & $\ldots$ & $\ldots$ & $\ldots$ & $\ldots$ \\
\hline 30 & $\ldots$ & $\ldots$ & $\ldots$ & 1015 \\
\hline 35 & $-\ldots$ & $\ldots$ & 90 & 1020 \\
\hline 40 & 980 & 1060 & 80 & 1035 \\
\hline 45 & 1010 & 1060 & 50 & 1025 \\
\hline 50 & 1000 & 1060 & 50 & $1180 ?$ \\
\hline 55 & $\ldots$ & 1050 & $\ldots$ & $\ldots$ \\
\hline 60 & $\ldots$ & $1180 ?$ & $\ldots$ & 1115 \\
\hline 65 & 1100 & 1130 & 30 & \\
\hline 2 Velocity from near to far receiver. & & & \\
\hline
\end{tabular}


Table 4. Compressional (P-) wave cross-hole velocity data comparison of forward ( $\mathrm{ZO2}$ ) and reverse ( $\mathrm{ZO3})$ direction results

\begin{tabular}{||c|c|c|c|c||}
\hline \multirow{2}{*}{ Depth } & \multicolumn{3}{|c|}{ P-wave velocities (ft/sec) } & \multirow{2}{*}{ Mean } \\
\cline { 2 - 5 } & Zne & Z03 & Difference & \\
\cline { 2 - 5 } & $\ldots$ & $\ldots$ & & \\
\hline 10 & $\ldots$ & $\ldots$ & & \\
\hline 15 & $\ldots$ & $\ldots$ & & 5200 \\
\hline 20 & $\ldots$ & $\ldots$ & & 5340 \\
\hline 25 & 5200 & $\ldots$ & $\ldots$ & 5635 \\
\hline 30 & 5310 & 5370 & 60 & 5505 \\
\hline 35 & 5640 & 5630 & 10 & 5150 \\
\hline 40 & 5140 & 5470 & 330 & 5500 \\
\hline 45 & 5100 & 5200 & 100 & 5375 \\
\hline 50 & 5540 & 5460 & 80 & 5535 \\
\hline 55 & 5120 & 5630 & 510 & 5260 \\
\hline 60 & 5210 & 5860 & 650 & Mean5367 \\
\hline 65 & 5250 & 5270 & 20 & Range \pm 250 \\
\hline & & & & \\
\hline
\end{tabular}




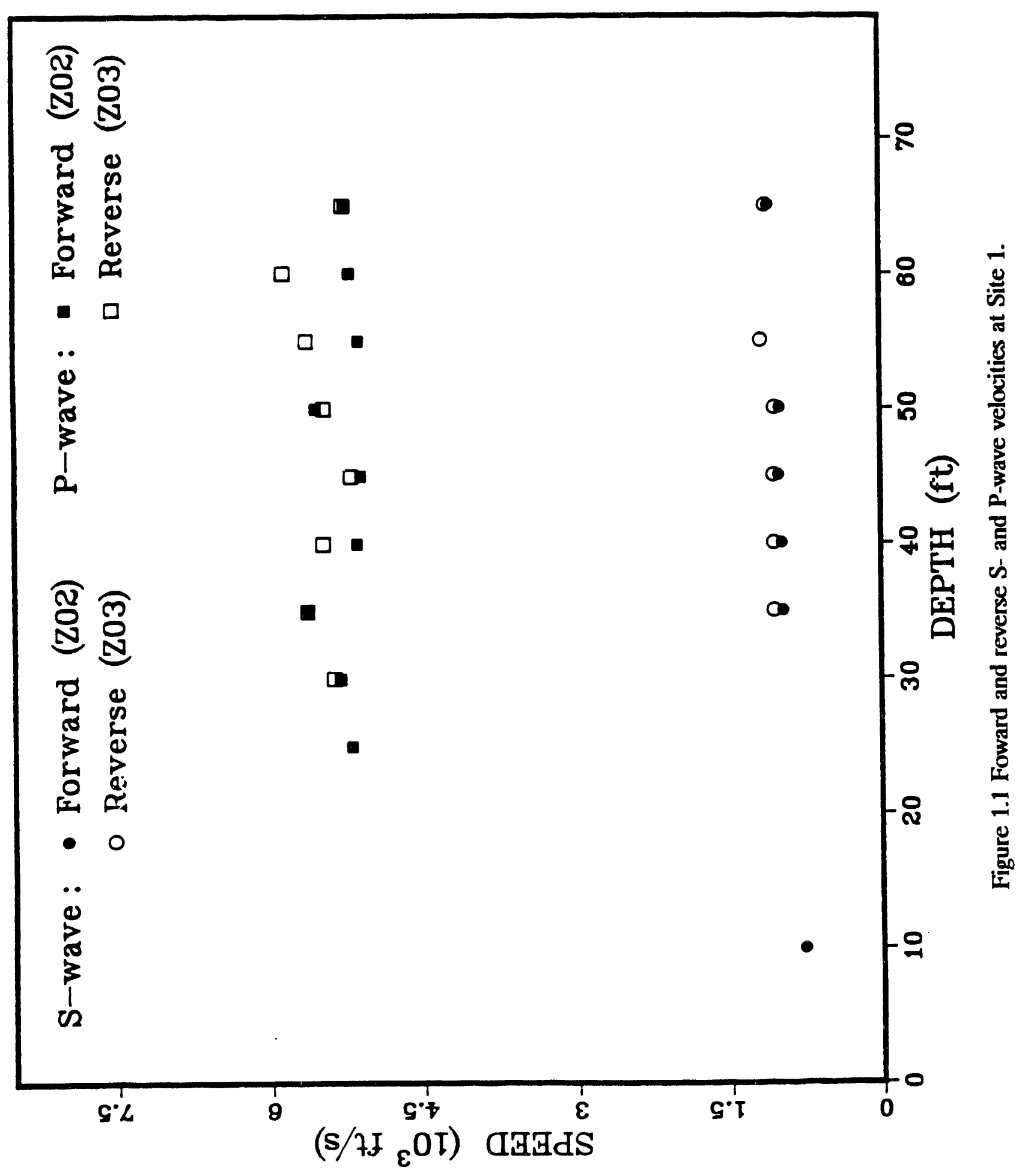




\section{APPENDLX 2}

SITE 2 


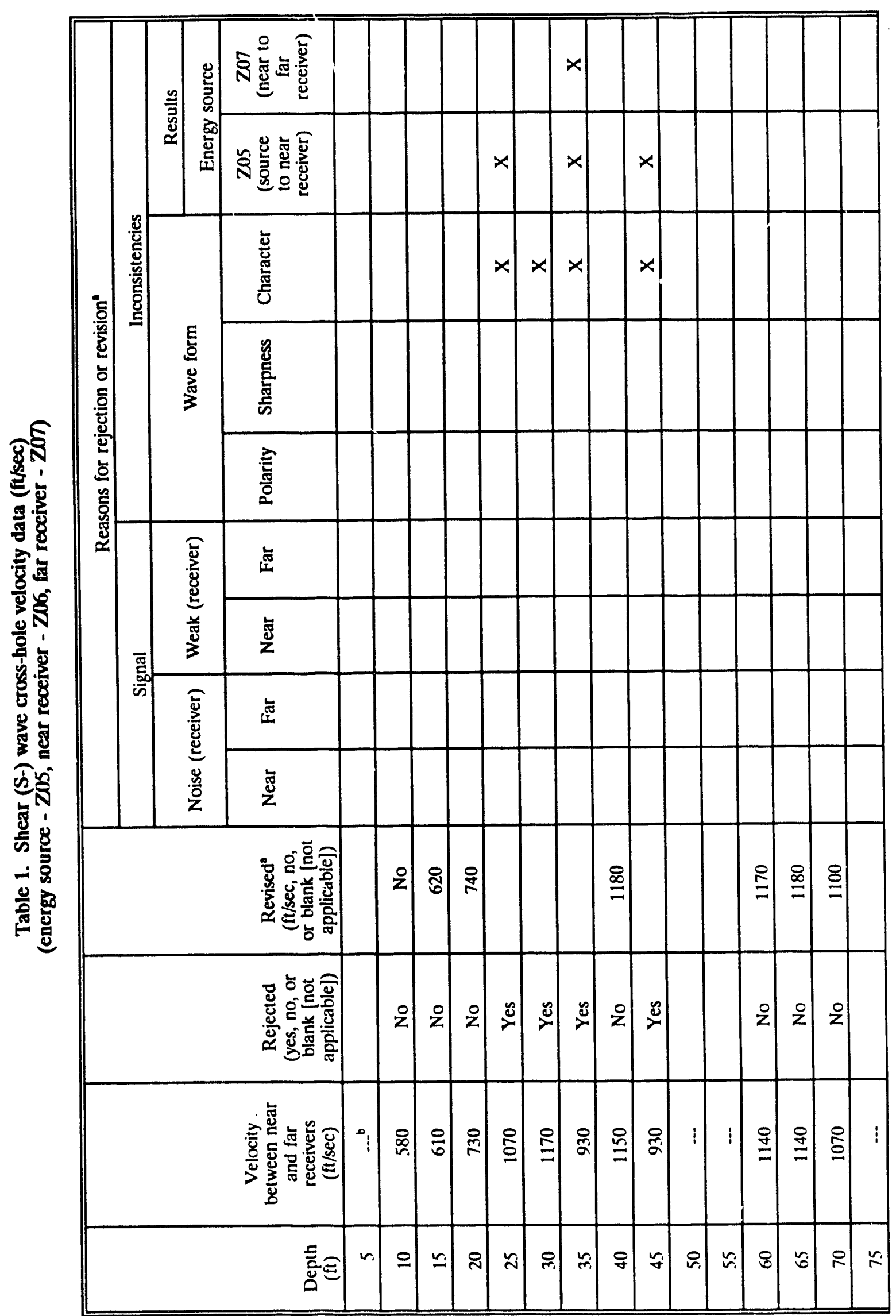




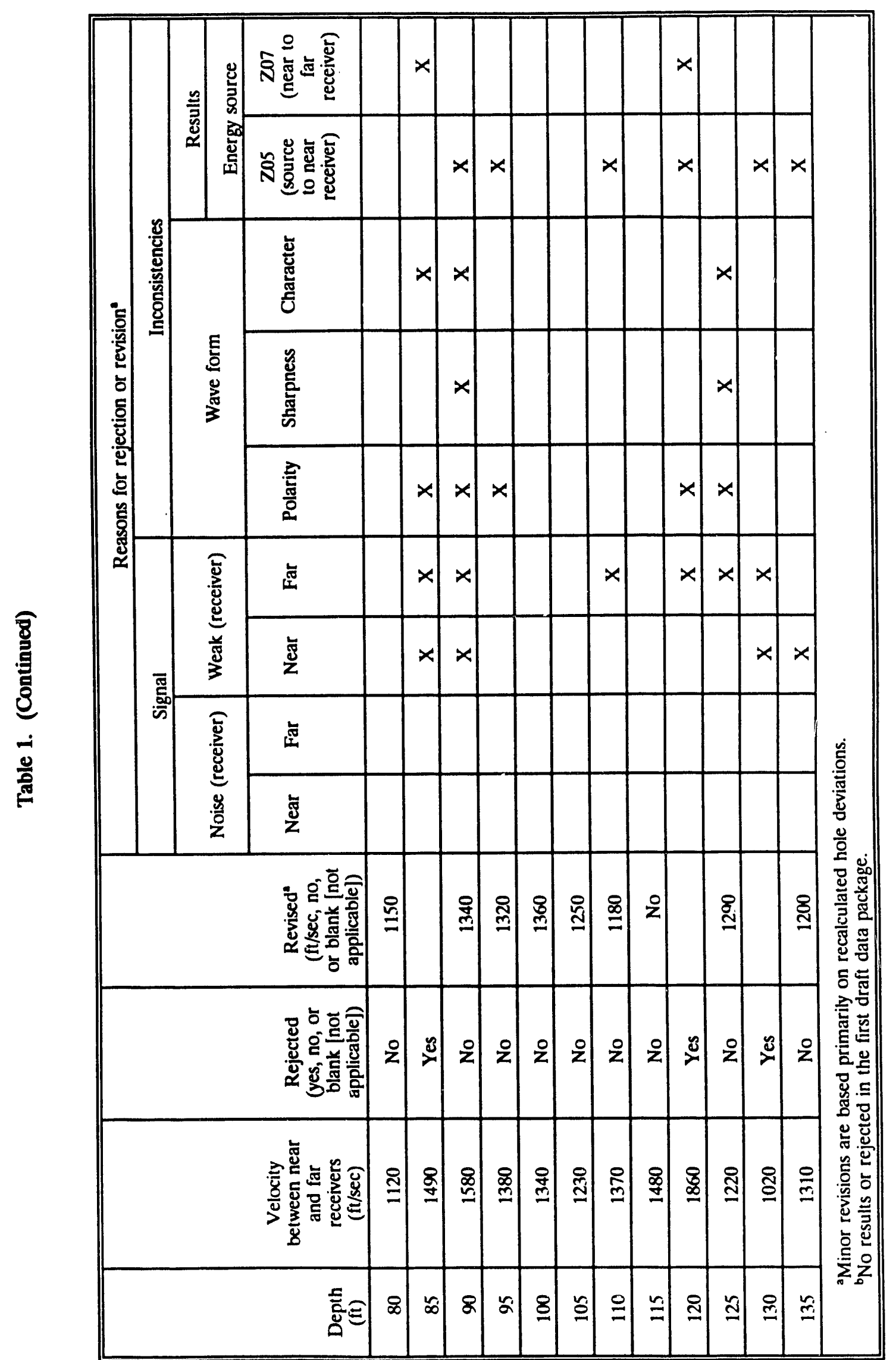




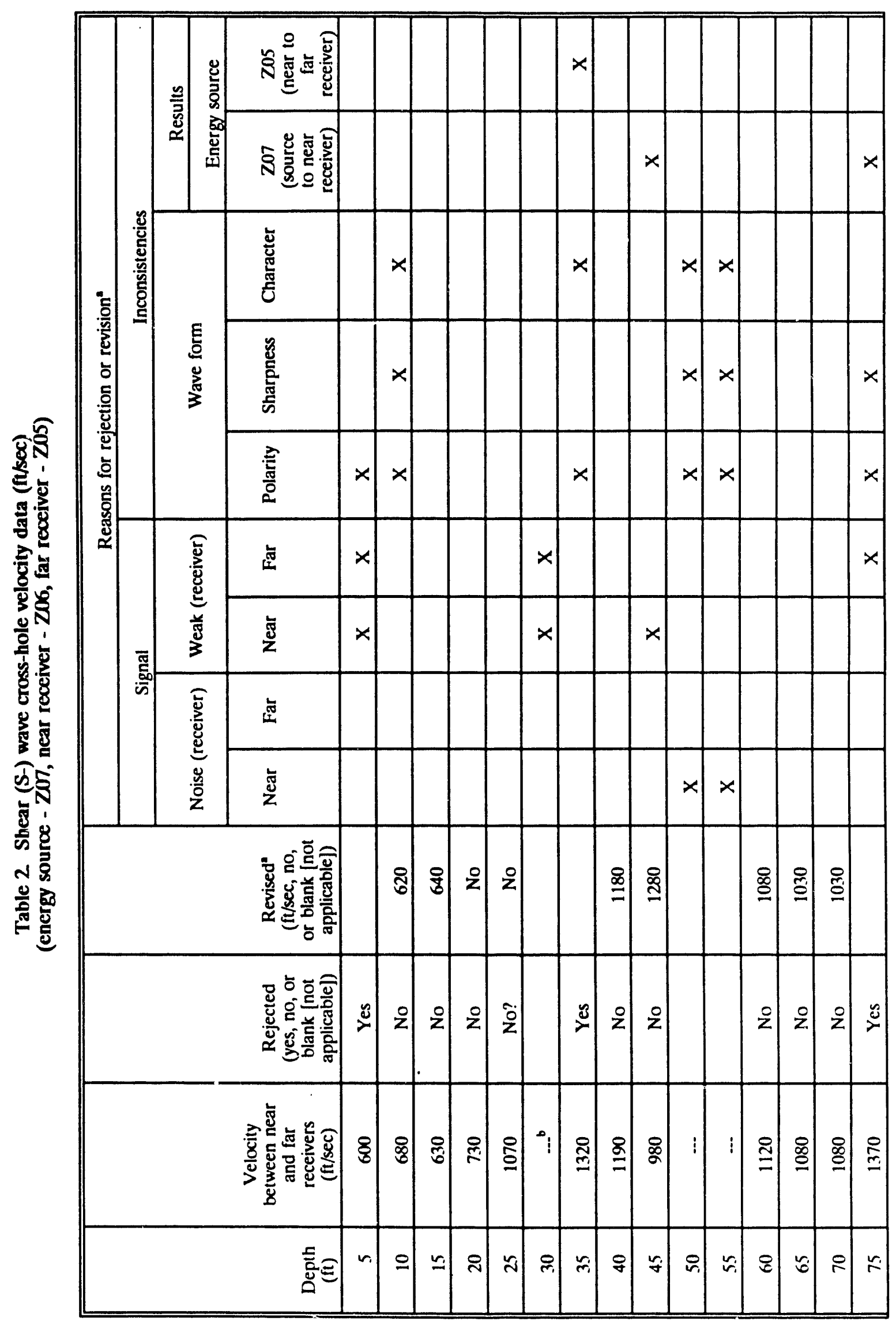




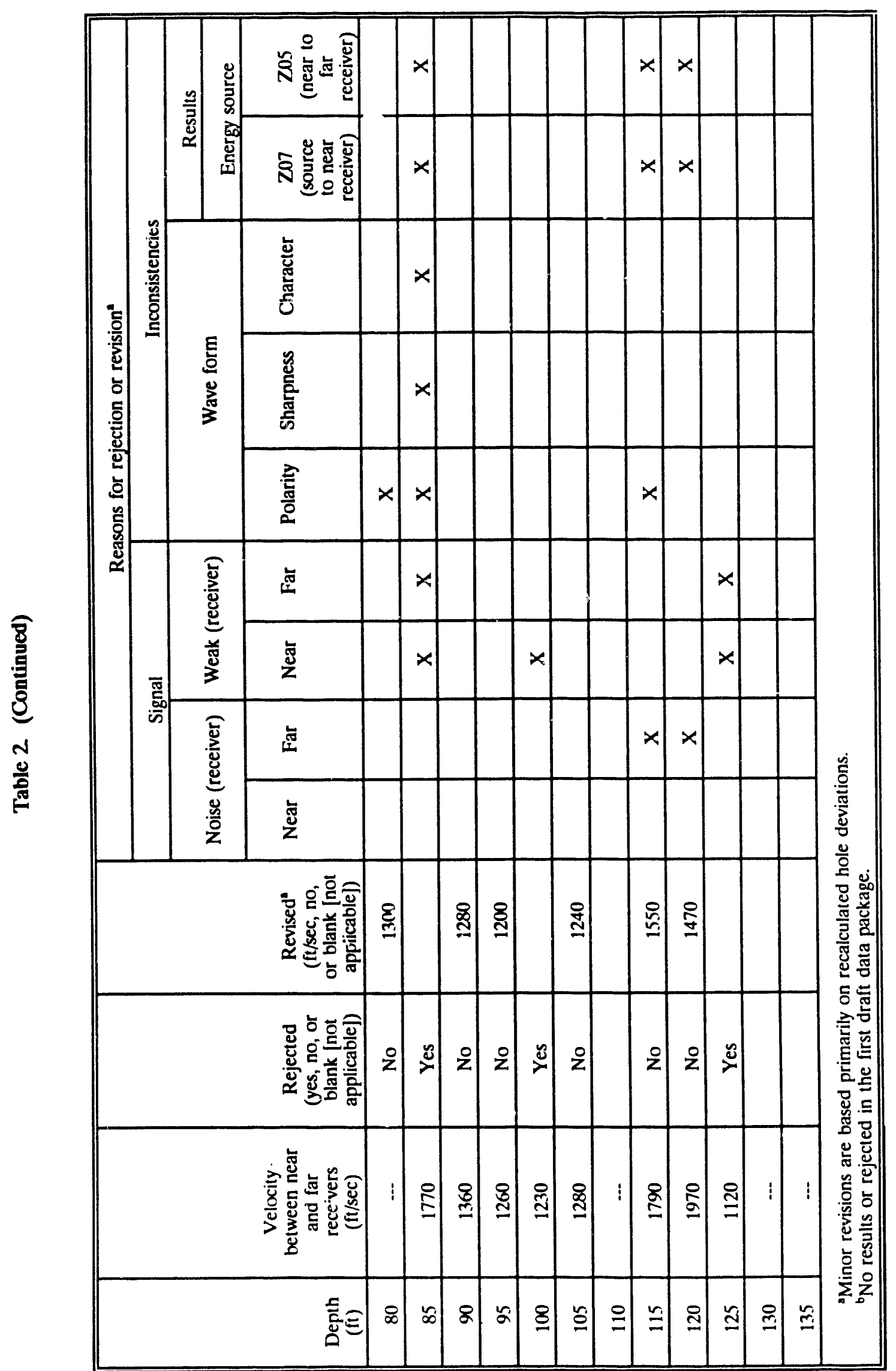


Table 3. Shear (S-) wave cross-hole velocity data [comparison of forward (Z05) and reverse (Z07) direction results]

\begin{tabular}{|c|c|c|c|c|}
\hline \multirow[b]{2}{*}{ Depth } & \multicolumn{2}{|c|}{ Energy source } & \multirow[b]{2}{*}{ Difference } & \multirow[b]{2}{*}{ Mean } \\
\hline & $\mathrm{Z} 05$ & $\mathbf{Z 0 7}$ & & \\
\hline 5 & $\ldots$ & - & - & -- \\
\hline 10 & 580 & 620 & 40 & 600 \\
\hline 15 & 620 & 640 & 20 & 630 \\
\hline 20 & 740 & 730 & 10 & 735 \\
\hline 25 & - & 1070 & $\ldots$ & 1070 \\
\hline 30 & - & - & - & $\ldots$ \\
\hline 35 & - & - & -- & $\cdots$ \\
\hline 40 & 1180 & 1180 & 0 & 1180 \\
\hline 45 & - & 1280 & $\cdots$ & 1280 \\
\hline 50 & $\ldots$ & - & $\cdots$ & $\cdots$ \\
\hline 55 & $\cdots$ & $\cdots$ & $\cdots$ & $\cdots$ \\
\hline 60 & 1170 & 1080 & 90 & 1125 \\
\hline 65 & 1180 & 1030 & 150 & 1105 \\
\hline 70 & 1100 & 1030 & 70 & 1065 \\
\hline 75 & - & - & -- & $\cdots$ \\
\hline 80 & 1150 & 1300 & 150 & 1225 \\
\hline 85 & - & - & -- & $\cdots$ \\
\hline 90 & 1340 & 1280 & 60 & 1310 \\
\hline 95 & 1320 & 1200 & 120 & 1260 \\
\hline 100 & 1360 & - & $\cdots$ & 1360 \\
\hline 105 & 1250 & 1240 & 10 & 1245 \\
\hline 110 & 1180 & - & - & 1180 \\
\hline 115 & 1480 & 1550 & 70 & 1515 \\
\hline 120 & $\cdots$ & 1470 & $\cdots$ & 1470 \\
\hline 125 & 1290 & - & $\ldots$ & 1290 \\
\hline 130 & $\ldots$ & $\cdots$ & $\cdots$ & 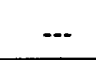 \\
\hline 135 & 1200 & $\cdots$ & --- & 1200 \\
\hline
\end{tabular}


Table 4. Compressional (P-) wave cross-hole velocity comparison of forward (Z05) and reverse (Z07) direction results

\begin{tabular}{|c|c|c|c|c|}
\hline \multirow[b]{2}{*}{ Depth } & \multicolumn{2}{|c|}{ Energy source } & \multirow[b]{2}{*}{ Difference } & \multirow[b]{2}{*}{ Mean } \\
\hline & Z05 & $\mathbf{Z 0 7}$ & & \\
\hline $5^{\circ}$ & - & - & - & $\ldots$ \\
\hline 10 & - & - & - & - \\
\hline 15 & 1920 & 1800 & 120 & 1860 \\
\hline 20 & 2570 & 2170 & 400 & 2370 \\
\hline 25 & 3200 & 2830 & 370 & 3015 \\
\hline 30 & 3650 & 3110 & 540 & 3380 \\
\hline 35 & 4940 & 4560 & 380 & 4750 \\
\hline 40 & 4620 & 4360 & 260 & 4490 \\
\hline 45 & 6730 & 4530 & 1000 & 5630 \\
\hline 50 & - & - & - & $\cdots$ \\
\hline 55 & 5800 & 3730 & 2070 & 4775 \\
\hline 60 & 5830 & 5450 & 380 & 5640 \\
\hline $65^{\circ}$ & 5910 & - & - & 5910 \\
\hline $70^{b}$ & - & - & $\cdots$ & $\cdots$ \\
\hline 75 & 4920 & 4800 & 120 & 4860 \\
\hline 80 & 6190 & - & $\cdots$ & 6190 \\
\hline 85 & 6570 & 6300 & 270 & 6435 \\
\hline 90 & 7370 & 6150 & 1220 & 6770 \\
\hline 95 & 6500 & 6040 & 460 & 6270 \\
\hline 100 & 6330 & 6320 & 10 & 6315 \\
\hline 105 & 6650 & 5980 & 670 & 6315 \\
\hline 110 & 6330 & 6080 & 250 & 6205 \\
\hline 115 & 6910 & - & - & 6910 \\
\hline 120 & - & $\therefore$ & - & $\cdots$ \\
\hline 125 & 5610 & 6160 & 550 & 5835 \\
\hline 130 & 5230 & 5540 & 310 & 5385 \\
\hline $135^{b}$ & 5570 & - & - & 5570 \\
\hline $\begin{array}{r}\text { 'P-way } \\
\text { receiver fro } \\
{ }^{6} \mathrm{P} \text {-wa } \\
135 \mathrm{ft} \text {. }\end{array}$ & $\begin{array}{l}\text { ased } 0 \\
\text { ased } 0\end{array}$ & $\begin{array}{l}\text { ar-rece } \\
\text { arrival }\end{array}$ & $\begin{array}{l}\text { nes (no P-w } \\
\text { en near- and }\end{array}$ & $\begin{array}{l}\text { d by far } \\
\text { s, from } 70 \text { to }\end{array}$ \\
\hline
\end{tabular}




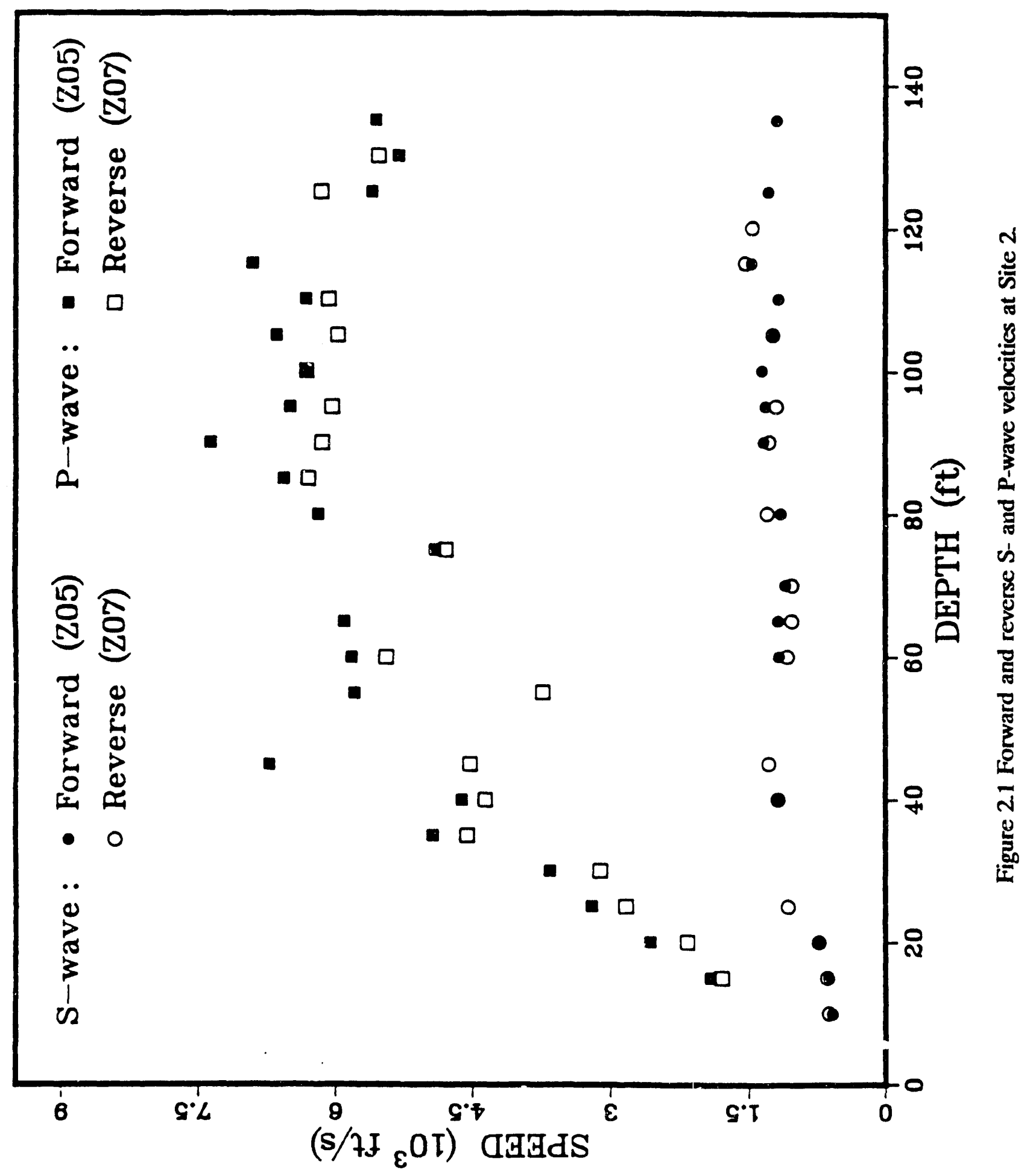


APPENDIX 3

SITE 3 


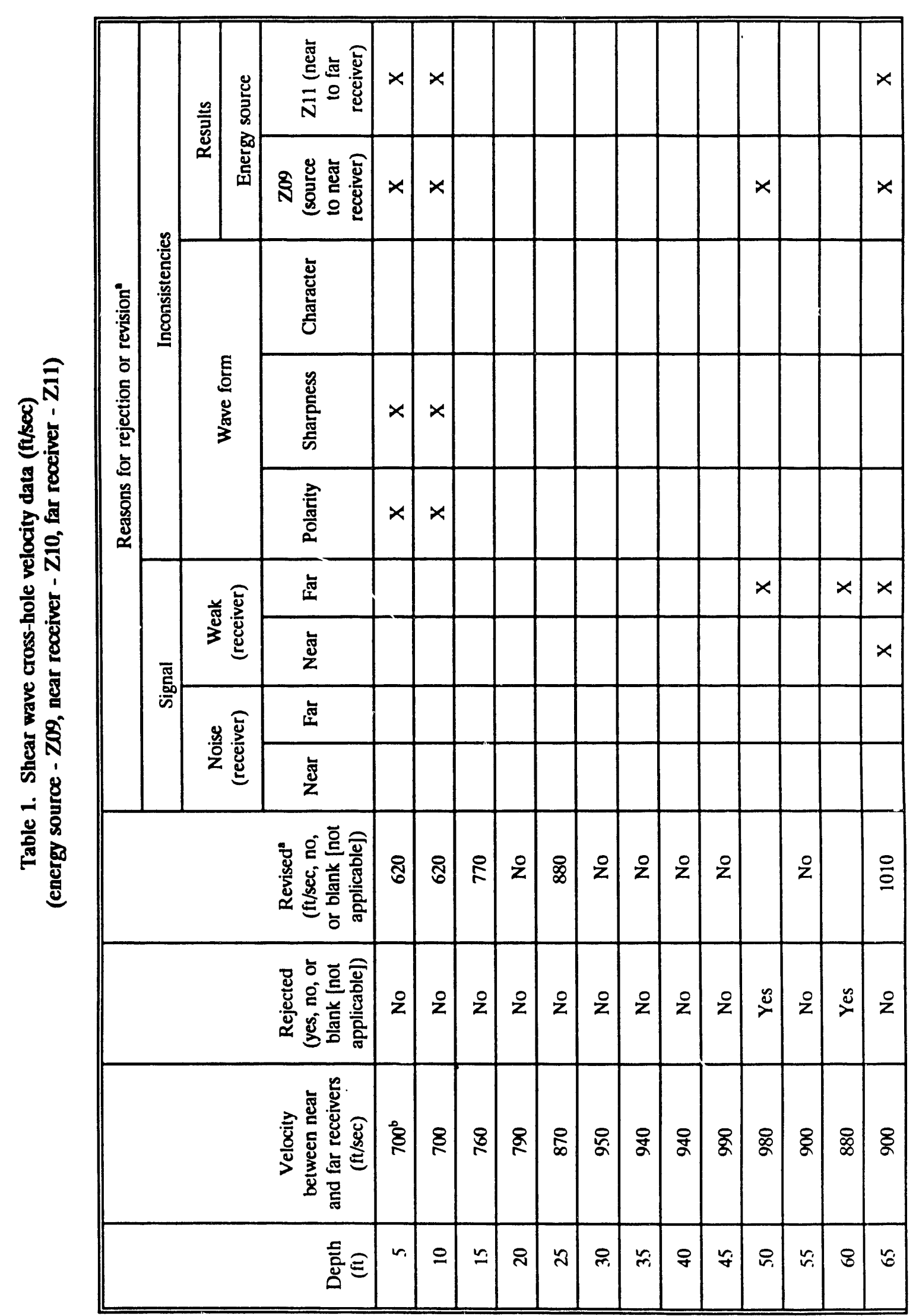




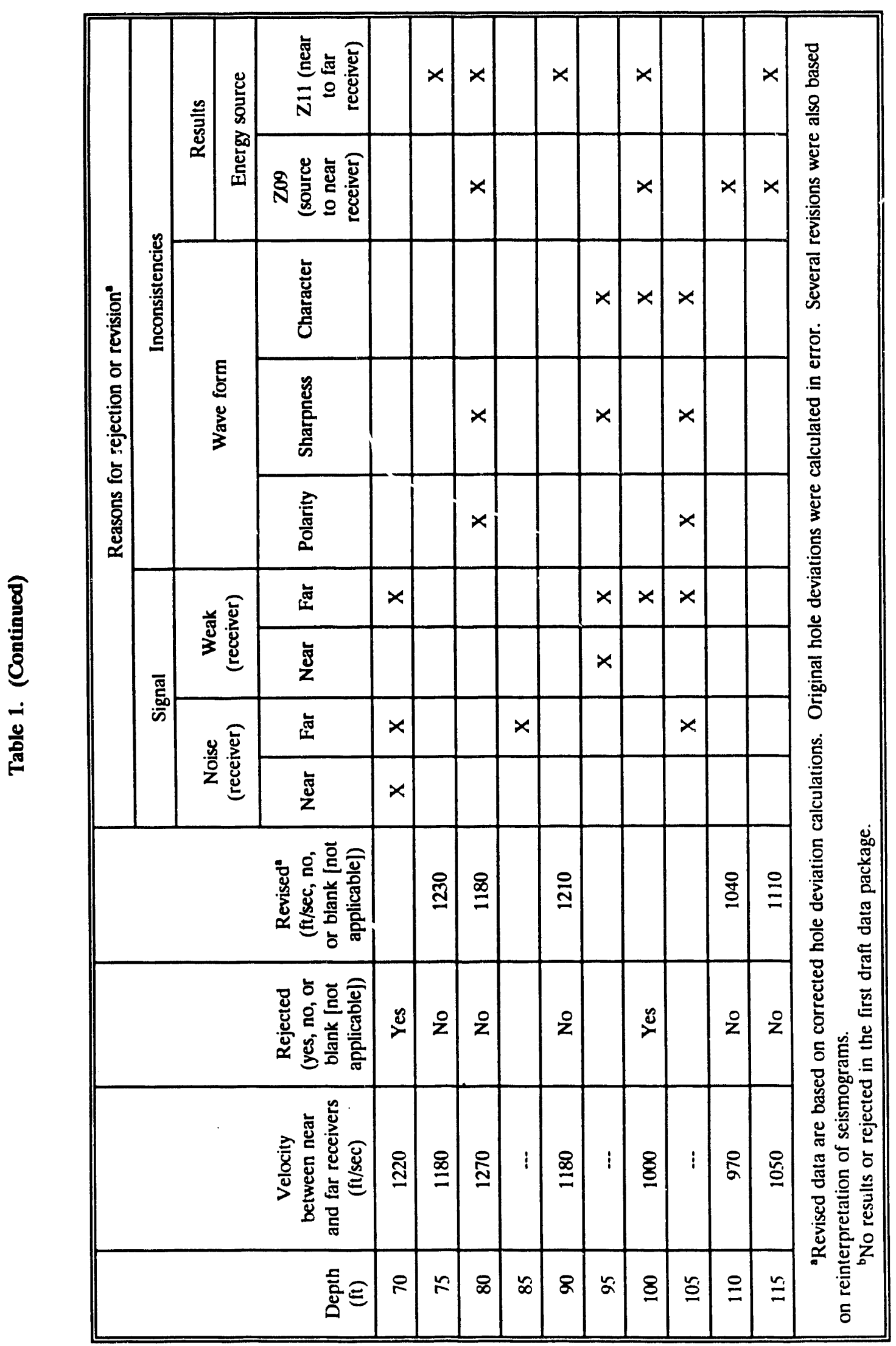




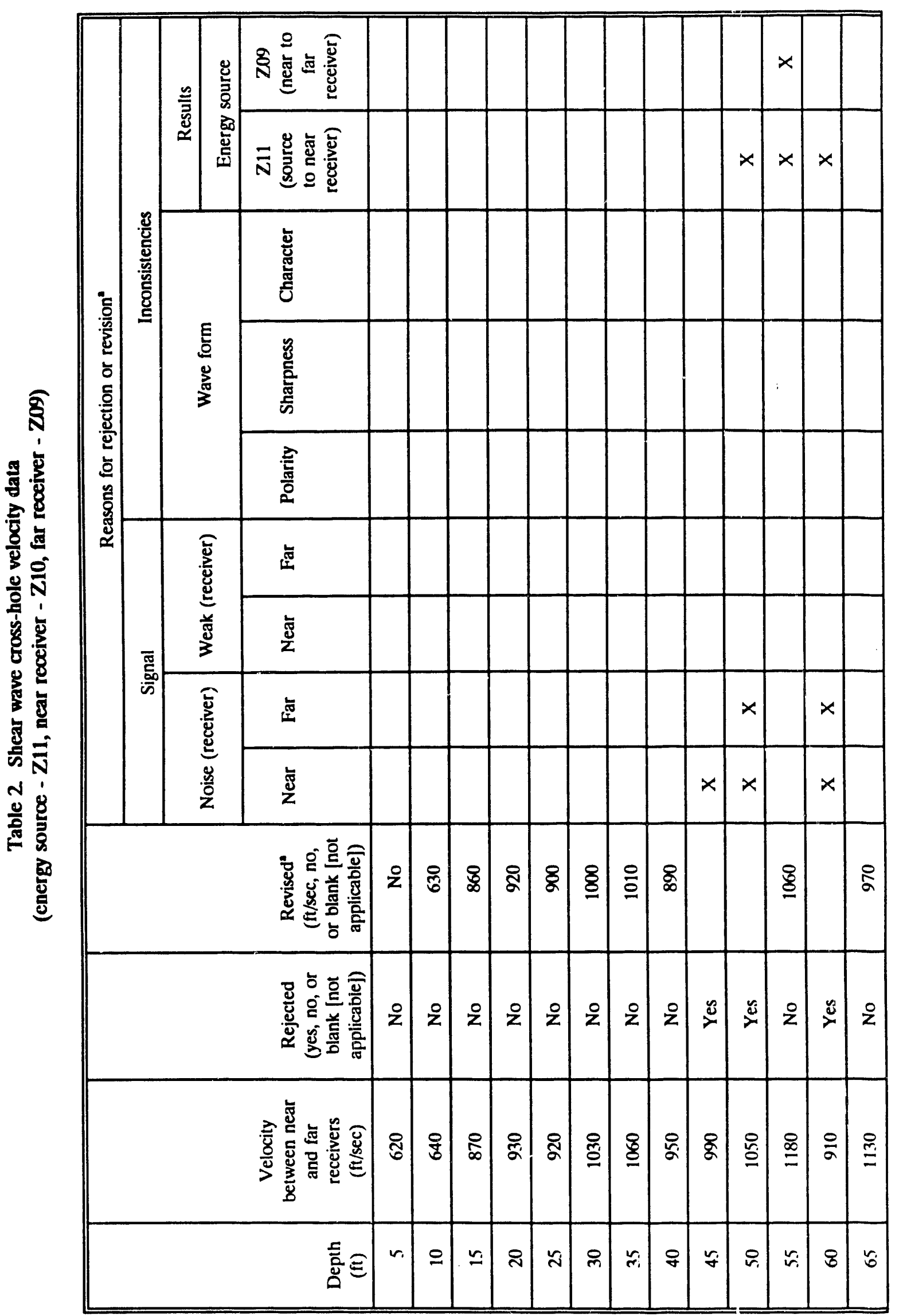




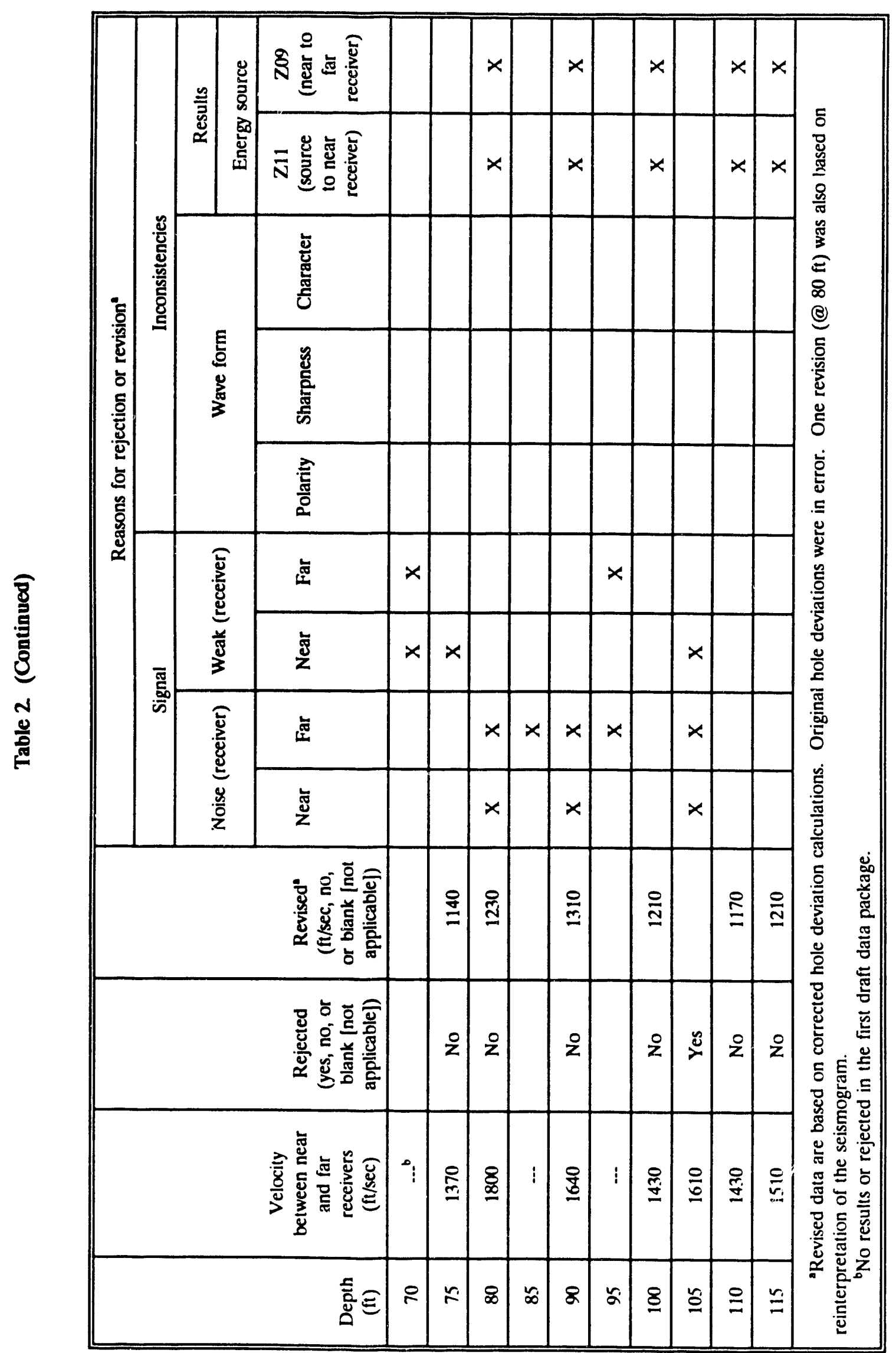


Table 3. Shear (S-) wave cross-hole velocity (ft/sec) summary [comparison of forward (Z09) and reverse (Z11) direction results]

\begin{tabular}{|c|c|c|c|c|}
\hline \multirow[b]{3}{*}{ Depth (ft) } & \multicolumn{4}{|c|}{$\mathrm{S}$-wave velocities $(\mathrm{ft} / \mathrm{sec})$} \\
\hline & \multicolumn{2}{|c|}{ Energy source" } & \multirow[b]{2}{*}{ Difference } & \multirow[b]{2}{*}{ Mean } \\
\hline & $\mathbf{Z O 9}$ & Z11 & & \\
\hline 5 & 620 & 620 & 0 & 620 \\
\hline 10 & 620 & 630 & 10 & 625 \\
\hline 15 & 770 & 860 & 90 & 815 \\
\hline 20 & 790 & 920 & 130 & 855 \\
\hline 25 & 880 & 900 & 20 & 890 \\
\hline 30 & 950 & 1000 & 50 & 975 \\
\hline 35 & 940 & 1010 & 70 & 975 \\
\hline 40 & 940 & 890 & 50 & 915 \\
\hline 45 & 990 & $\cdots$ & $\cdots$ & 990 \\
\hline 50 & $\cdots$ & $\cdots$ & $-\cdots$ & -- \\
\hline 55 & 900 & 1060 & 160 & 980 \\
\hline 60 & $\cdots$ & -- & $\cdots$ & $-\cdots$ \\
\hline 65 & 1010 & 970 & 40 & 990 \\
\hline 70 & $\cdots$ & -- & $\cdots$ & $-\cdots$ \\
\hline 75 & 1230 & 1140 & 90 & 1185 \\
\hline 80 & 1180 & 1230 & 50 & 1205 \\
\hline 85 & -- & $\cdots$ & $\cdots$ & $\cdots$ \\
\hline 90 & 1210 & 1310 & 100 & 1250 \\
\hline 95 & $\cdots$ & $\cdots$ & $\cdots$ & $\cdots$ \\
\hline 100 & $\cdots$ & 1210 & $\cdots$ & 1210 \\
\hline 105 & $\cdots$ & -- & $\cdots$ & $\cdots$ \\
\hline 110 & 1040 & 1170 & 130 & 1105 \\
\hline 115 & 1110 & 1210 & 100 & 1160 \\
\hline
\end{tabular}


Table 4. Compressional P-wave cross-hole velocity ( $\mathrm{ft} / \mathrm{sec}$ ) data [comparison of forward (Z09) and reverse (Z11) direction results]

\begin{tabular}{|c|c|c|c|c|}
\hline \multirow[b]{3}{*}{ Depth (ft) } & \multicolumn{4}{|c|}{ P-wave velocities ( $\mathrm{ft} / \mathrm{sec}$ ) } \\
\hline & \multicolumn{2}{|c|}{ Energy source" } & \multirow[b]{2}{*}{ Difference } & \multirow[b]{2}{*}{ Mean } \\
\hline & $\mathbf{Z} 09$ & Z11 & & \\
\hline 5 & $\cdots$ & $\cdots$ & -- & \\
\hline 10 & -- & -- & $\cdots$ & \\
\hline 15 & $\cdots$ & 1950 & -- & 1950 \\
\hline 20 & 1520 & 2830 & 1310 & 2175 \\
\hline 25 & 5690 & $\cdots$ & $\cdots$ & 5690 \\
\hline 30 & 4060 & 3390 & 670 & 3725 \\
\hline 35 & 5070 & $\cdots$ & $\cdots$ & 5070 \\
\hline 40 & 3780 & 2790 & 990 & 3285 \\
\hline 45 & 3930 & 5720 & 1790 & 4825 \\
\hline 50 & 3630 & 5310 & 1680 & 4470 \\
\hline 55 & 5240 & 6690 & 1450 & 5965 \\
\hline 60 & 5810 & 5390 & 420 & 5600 \\
\hline 65 & 5410 & 6130 & 720 & 5770 \\
\hline 70 & 5540 & 6390 & 850 & 5965 \\
\hline 75 & 6010 & 6310 & 300 & 6160 \\
\hline 80 & 6470 & 6860 & 390 & 6665 \\
\hline 85 & 7030 & 7160 & 130 & 7095 \\
\hline 90 & 6590 & 8030 & 1440 & 7310 \\
\hline 95 & 5750 & 6980 & 1230 & 6365 \\
\hline 100 & 5970 & 6040 & 70 & 6005 \\
\hline 105 & 5570 & 5690 & 120 & 5630 \\
\hline 110 & 5180 & 5670 & 490 & 5425 \\
\hline 115 & 5340 & 6010 & 670 & 5675 \\
\hline
\end{tabular}


Table 5. Measured down-hole shear (S-) wave velocities and range of calculated down-hole compressional (P-) wave velocities for selected depth intervals in Hole Z12

\begin{tabular}{|c|c|c|c|c|}
\hline \multirow[b]{2}{*}{ Depth interval (ft) } & \multirow[b]{2}{*}{$V_{1}(\mathrm{ft} / \mathrm{s})^{\prime}$} & \multicolumn{3}{|c|}{$V_{p}(f t / s)^{b}$} \\
\hline & & $\sigma-1 S D$ & $\boldsymbol{\sigma}$ & $\sigma+1 S D$ \\
\hline $130-195$ & 1290 & 5420 & 6375 & 8215 \\
\hline $195-265$ & 1545 & 6490 & 7635 & 9840 \\
\hline $265-334$ & 1155 & 4850 & 5710 & 7355 \\
\hline \multicolumn{5}{|c|}{$\begin{array}{l}\text { 'Measured } V_{1} \text { estimates, based on linear least-squares analyses of } S \text {-wave arrival times as } \\
\text { functions of depth. } \\
\text { 'Range of calculated downhole } V_{p} \text { values, based on mean values }(\sigma) \text { and one standard } \\
\text { deviation (1SD) above and below mean values of Poisson's ratio. Poisson's ratios are based } \\
\text { on measured cross-hole velocities }\left(V_{s} \text { and } V_{p}\right) \text { at } 5 \mathrm{ft} \text { intervals from the water table to the } \\
\text { bottom of the holes. }\end{array}$} \\
\hline
\end{tabular}




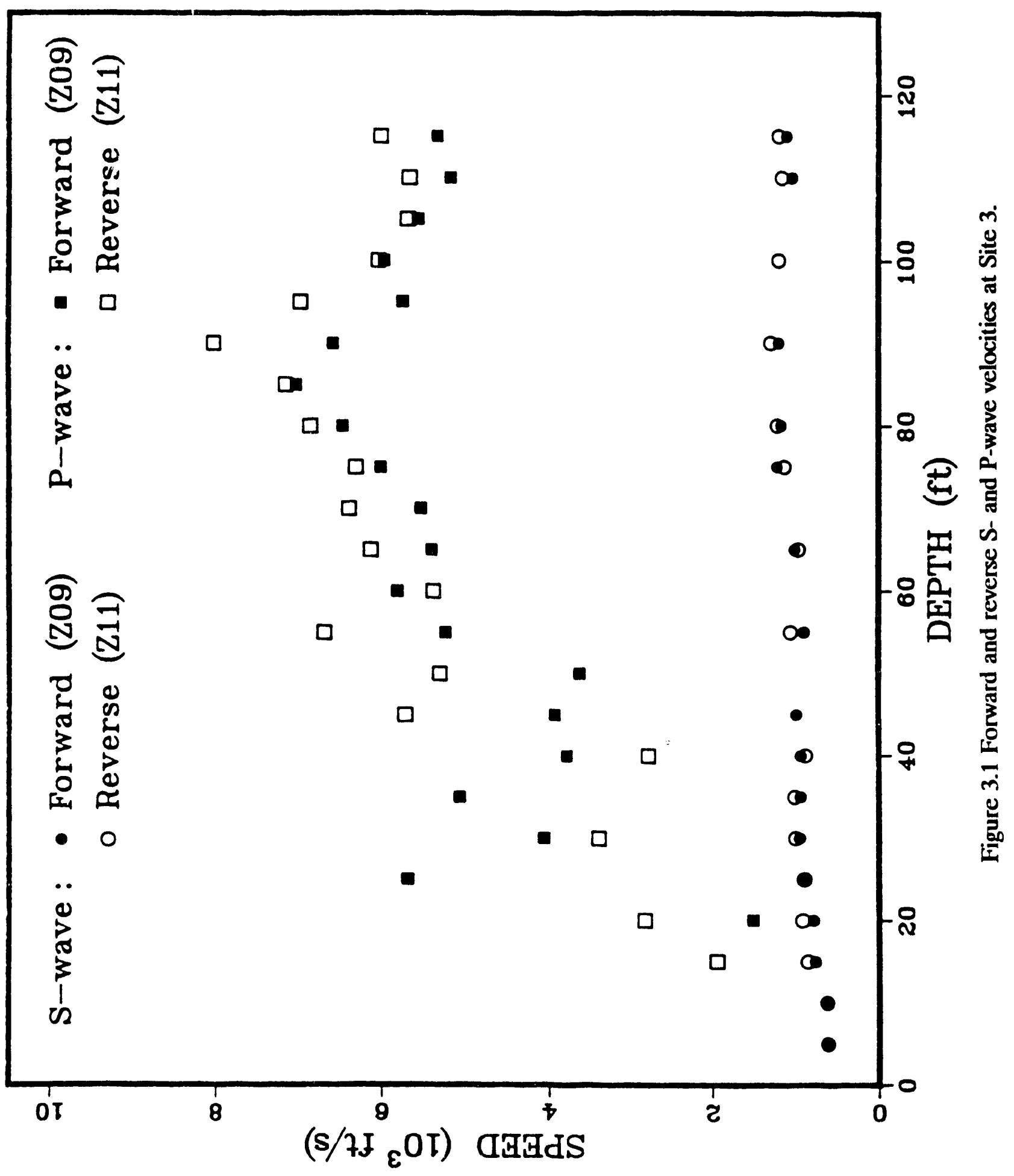


APPENDIX 4

SITE 4 


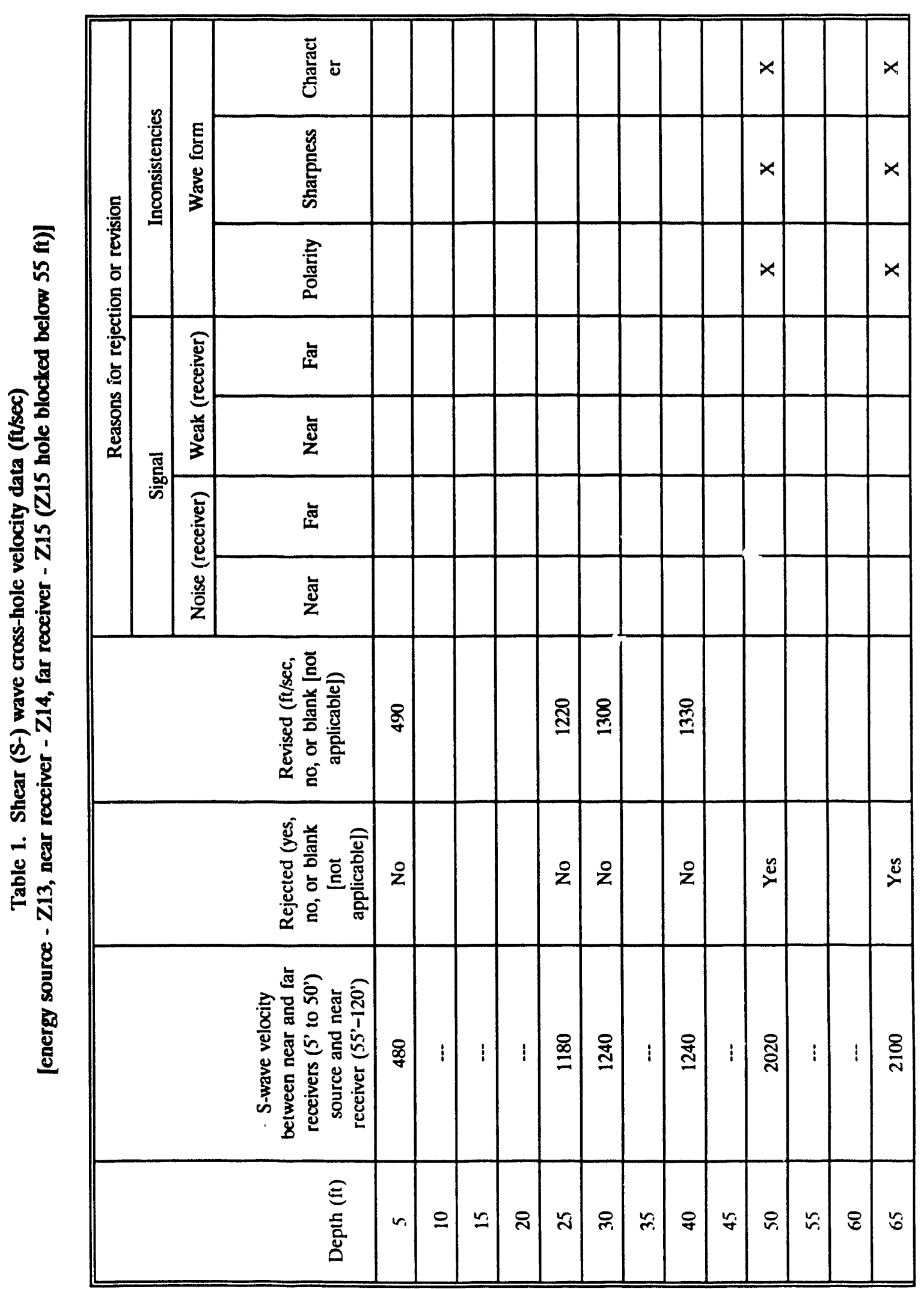




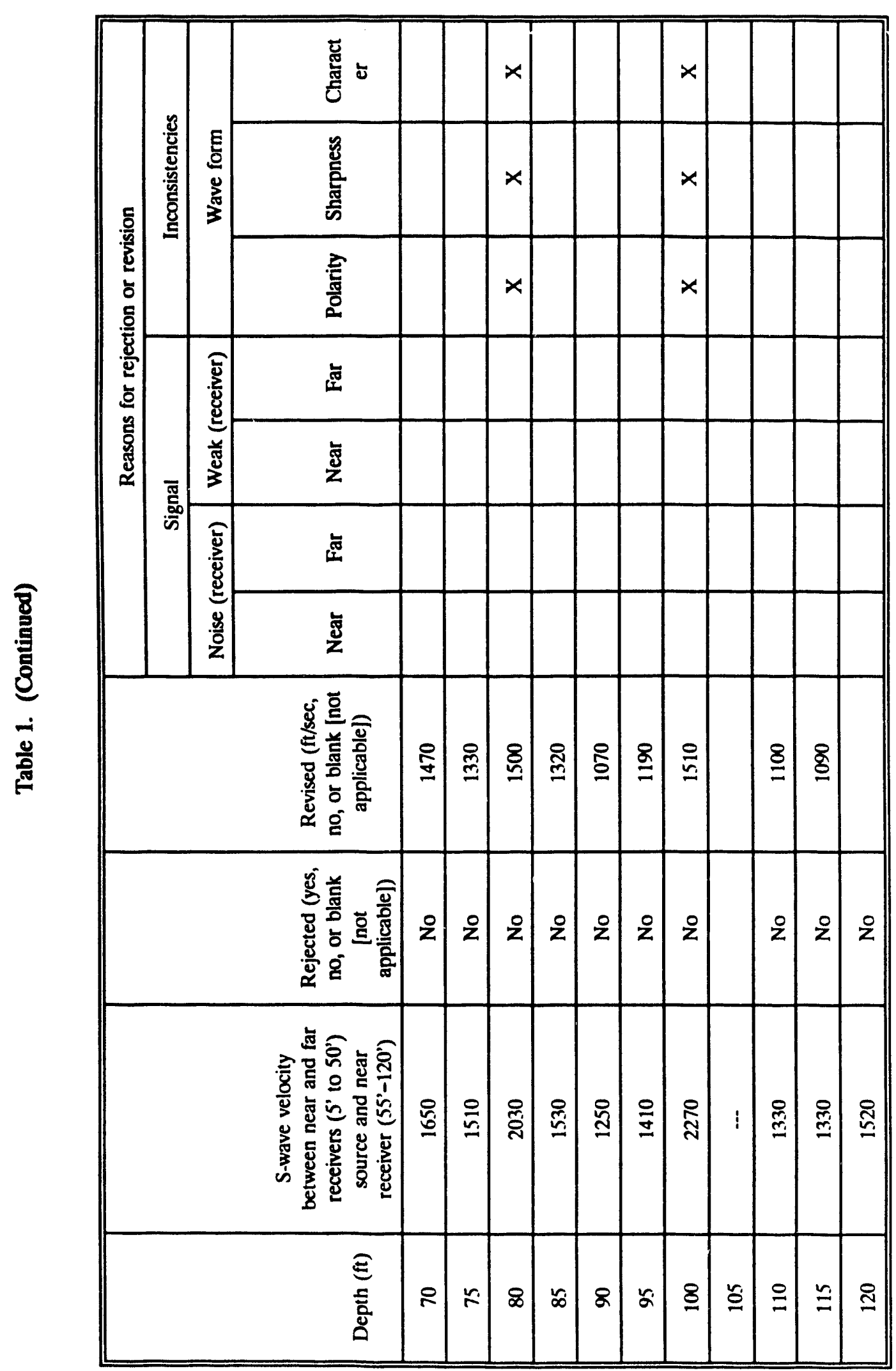


Table 2 Compressional (P-) wave cross-hole velocity (ft/sec) data [energy source - Z13, near receiver - Z14, far receiver - Z15 (hole Z15 blocked below $55 \mathrm{ft}$ )]

\begin{tabular}{|c|c|c|c|c|}
\hline \multirow[b]{3}{*}{ Depth (ft) } & \multicolumn{4}{|c|}{ P-wave velocities $(\mathrm{ft} / \mathrm{sec})^{\mathrm{a}}$} \\
\hline & \multicolumn{2}{|c|}{ Energy source" } & \multirow[b]{2}{*}{ Difference } & \multirow[b]{2}{*}{ Mean } \\
\hline & $\mathrm{Z} 13$ & $\mathrm{Z} 15$ & & \\
\hline 5 & -- & -- & & \\
\hline 10 & --- & $\cdots$ & & \\
\hline 15 & --- & -- & & \\
\hline 20 & 4125 & $\cdots$ & & \\
\hline 25 & 2140 & $\cdots$ & & \\
\hline 30 & 3300 & $\cdots$ & & \\
\hline 35 & $\cdots$ & 1940 & & \\
\hline 40 & 3610 & $\cdots$ & & \\
\hline 45 & -- & 4400 & & \\
\hline 50 & 4020 & 3340 & 680 & 3680 \\
\hline 55 & $\cdots$ & 2010 & & \\
\hline 60 & $\ldots$ & $-\cdots$ & & \\
\hline 65 & 4255 & $\cdots$ & & \\
\hline 70 & 7680 & $-\cdots$ & & \\
\hline 75 & 7360 & & & \\
\hline 80 & 11,040 & & & \\
\hline 85 & 8190 & & & \\
\hline 90 & 7360 & & & \\
\hline 95 & 6615 & & & \\
\hline 100 & 6830 & & & \\
\hline 105 & 5600 & & & \\
\hline 110 & 5330 & & & \\
\hline 115 & 5410 & & & \\
\hline $\begin{array}{l}\text { 'Velocity } \mathrm{f} \\
115 \mathrm{ft} \text { ). }\end{array}$ & far re &,$v$ & source to & eiver ( \\
\hline
\end{tabular}


Table 3. Measured down-hole shear (S-) wave velocity and range of calculated compressional (P-) wave velocities from 123 to $322 \mathrm{ft}$ below the surface in Hole Z16

\begin{tabular}{|c|c|c|c|}
\hline \multirow[b]{2}{*}{$V_{1}(f t / s)^{2}$} & \multicolumn{3}{|c|}{$V_{p}(f t / s)^{b}$} \\
\hline & $\sigma-1 S D$ & $\sigma$ & $\sigma+1 S D$ \\
\hline 1550 & 7190 & 7605 & 8115 \\
\hline \multicolumn{4}{|c|}{$\begin{array}{l}\text { 'Measured } V_{1} \text { estimates, based on linear least-squares analyses of } S \text {-wave arrival times as } \\
\text { functions of depth. } \\
\text { 'Range of calculated downhole } V_{p} \text { values, based on mean values }(\sigma) \text { and one standard } \\
\text { deviation (1SD) above and below mean values of Poisson's ratio. Poisson's ratios are based } \\
\text { on measured cross-hole velocities }\left(V_{b} \text { and } V_{p}\right) \text { at } 5 \text { ft intervals from the water table to the } \\
\text { bottom of the holes. }\end{array}$} \\
\hline
\end{tabular}




\section{APPENDIX 5}

\section{SUMMARY OF S- AND P-WAVE VELOCITY ESTIMATES}


Table 1. Data summary, cross-hole S-wave velocities $\left(t_{4} / \mathrm{sec}\right)$

\begin{tabular}{|c|c|c|c|c|}
\hline \multirow[b]{2}{*}{ Depth (ft) } & \multicolumn{4}{|c|}{ Site } \\
\hline & 1 & 2 & 3 & 4 \\
\hline 5 & -.- & $\ldots$ & 620 & 490 \\
\hline 10 & 770 & 600 & 625 & $\ldots$ \\
\hline 15 & $\ldots$ & 630 & 815 & $\ldots$ \\
\hline 20 & -- & 735 & 855 & -.. \\
\hline 25 & $\ldots$ & 1070 & 890 & 1220 \\
\hline 30 & $\cdots$ & $\ldots$ & 975 & 1300 \\
\hline 35 & 1015 & $\ldots$ & 975 & --. \\
\hline 40 & 1020 & 1180 & 915 & 1330 \\
\hline 45 & 1035 & 1280 & 990 & $\ldots$ \\
\hline 50 & 1025 & $\ldots$ & $\ldots$ & $\ldots$ \\
\hline 55 & $1180 ?$ & $\ldots$ & 980 & $\ldots$ \\
\hline 60 & $\ldots$ & 1125 & $\ldots$ & --- \\
\hline 65 & 1115 & 1105 & 990 & $\ldots$ \\
\hline 70 & & 1065 & $\ldots$ & 1470 \\
\hline 75 & & $\ldots$ & 1185 & 1330 \\
\hline 80 & & 1225 & 1205 & 1500 \\
\hline 85 & & $\ldots$ & $\ldots$ & 1320 \\
\hline 90 & & 1310 & 1250 & 1070 \\
\hline 95 & & 1260 & $\ldots$ & 1190 \\
\hline 100 & & 1360 & 1210 & 1510 \\
\hline 105 & & 1245 & $\ldots$ & $\ldots$ \\
\hline 110 & & 1180 & 1105 & 1100 \\
\hline 115 & & 1515 & 1160 & 1090 \\
\hline 120 & & 1470 & & \\
\hline 125 & & 1290 & & \\
\hline 130 & & $\cdots$ & & \\
\hline 135 & & 1200 & & \\
\hline
\end{tabular}


Table 2 Data summary, measured down-hole S-wave velocities and calculated down-hole $\mathbf{P}$-wave velocities ( $\mathrm{ft} / \mathrm{s}$ )

\begin{tabular}{|c|c|c|c|}
\hline Site & Depth interval (ft) & $\mathrm{V}_{.}$ & $\mathrm{V}_{\mathrm{p}}{ }^{\circ}$ \\
\hline 3 & $130-195$ & 1290 & 6375 \\
& $195-265$ & 1545 & 7635 \\
& $265-334$ & 1155 & 5710 \\
\hline $1,2,4$ & $123-322$ & 1550 & 7605 \\
\hline CCalculated $\mathrm{V}_{\mathrm{p}}$, based on mean value Poisson's ratio. \\
\hline
\end{tabular}


Table 3. Data summary, cross-hole $\mathrm{P}$-wave velocities ( $\mathrm{f} / \mathrm{sec}$ )

\begin{tabular}{|c|c|c|c|c|}
\hline \multirow[b]{2}{*}{ Depth (ft) } & \multicolumn{4}{|c|}{ Site } \\
\hline & 1 & 2 & 3 & 4 \\
\hline 5 & $\cdots$ & -- & $\cdots$ & $\cdots$ \\
\hline 10 & $\cdots$ & -- & -- & $\cdots$ \\
\hline 15 & $-\cdot$ & 1860 & 1950 & $\cdots$ \\
\hline 20 & -- & 2370 & 2175 & 4125 \\
\hline 25 & 5200 & 3015 & 5690 & 2140 \\
\hline 30 & 5340 & 3380 & 3725 & 3300 \\
\hline 35 & 5635 & 4750 & 5070 & $\cdots$ \\
\hline 40 & 5305 & 4490 & 3285 & 3610 \\
\hline 45 & 5150 & 5630 & 4825 & $\cdots$ \\
\hline 50 & 5500 &.- & 4470 & 4020 \\
\hline 55 & 5375 & 4775 & 5965 & $\cdots$ \\
\hline 60 & 5535 & 5640 & 5600 & $\cdots$ \\
\hline 65 & 5260 & 5910 & 5770 & 4255 \\
\hline 70 & $\cdots$ & $\cdots$ & 5965 & 7680 \\
\hline 75 & -- & 4860 & 6160 & 7360 \\
\hline 80 & $\cdots$ & 6190 & 6665 & 11,040 \\
\hline 85 &.- & 6435 & 7095 & 8190 \\
\hline 90 & -- & 6770 & 7310 & 7360 \\
\hline 95 & -- & 6270 & 6365 & 6615 \\
\hline 100 & -- & 6315 & 6005 & 6830 \\
\hline 105 & $\cdots$ & 6315 & 5630 & 5600 \\
\hline 110 & -- & 6205 & 5425 & 5330 \\
\hline 115 & $\cdots$ & 6910 & 5675 & 5410 \\
\hline 120 & $\cdots$ & $\cdots$ & $\cdots$ & $\cdots$ \\
\hline 125 & -- & 5835 & $\cdots$ & $\cdots$ \\
\hline 130 & -.. & 5385 & $\cdots$ & $\ldots$ \\
\hline 135 & -.. & 5570 & $\cdots$ & -- \\
\hline
\end{tabular}




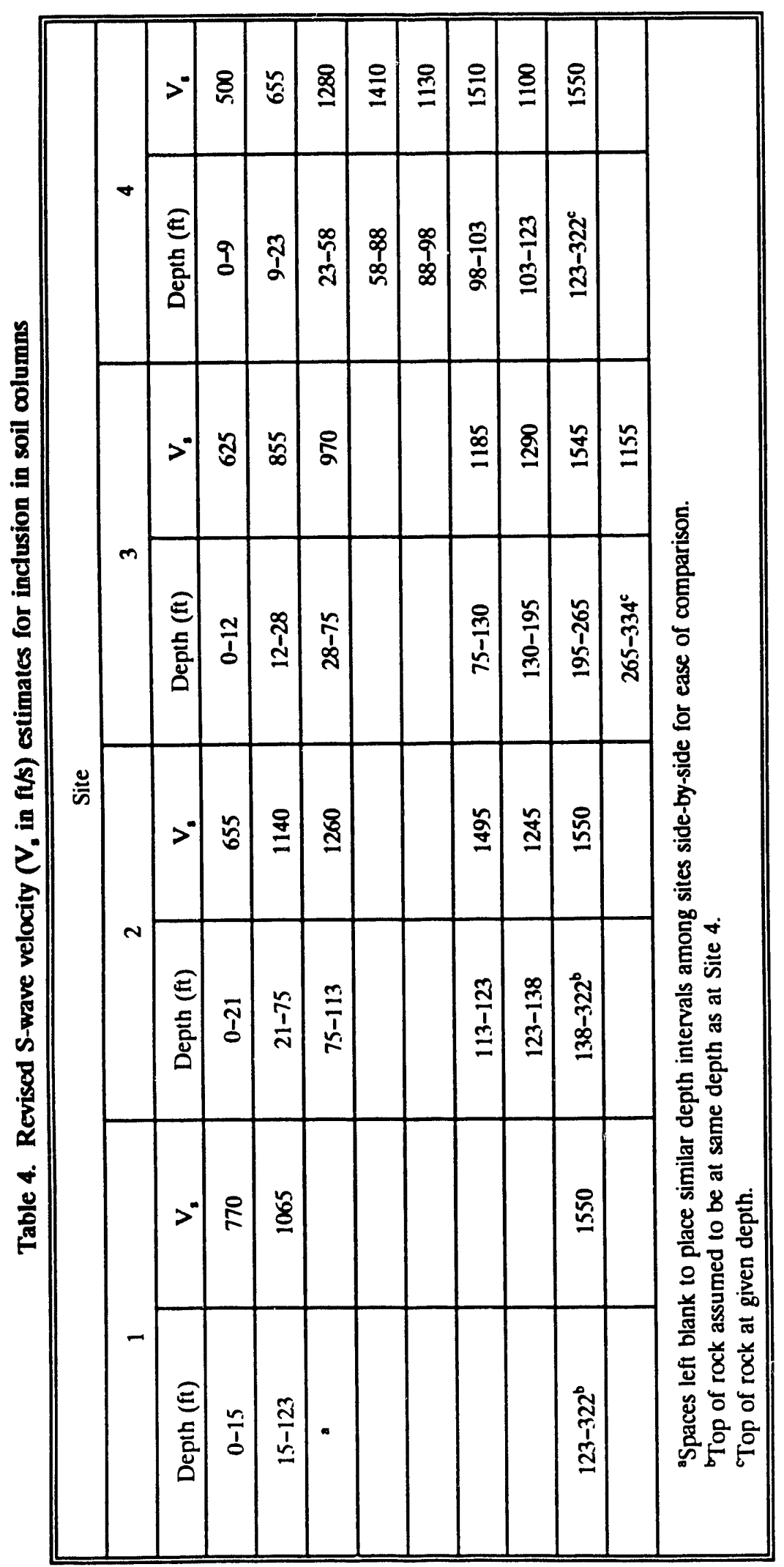




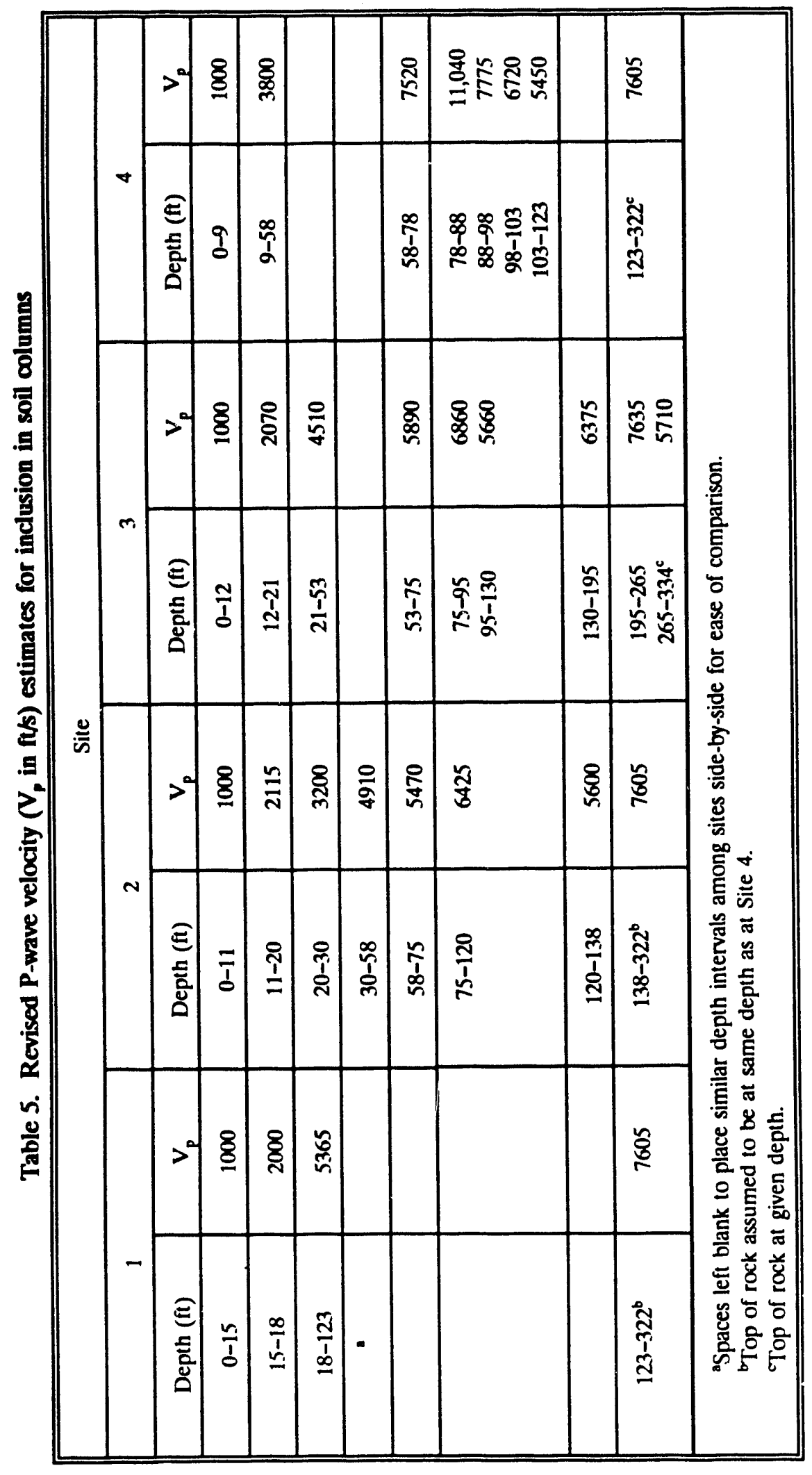


APPENDIX 6

SOIL COLUMNS AND SITE LOCATION MAP 


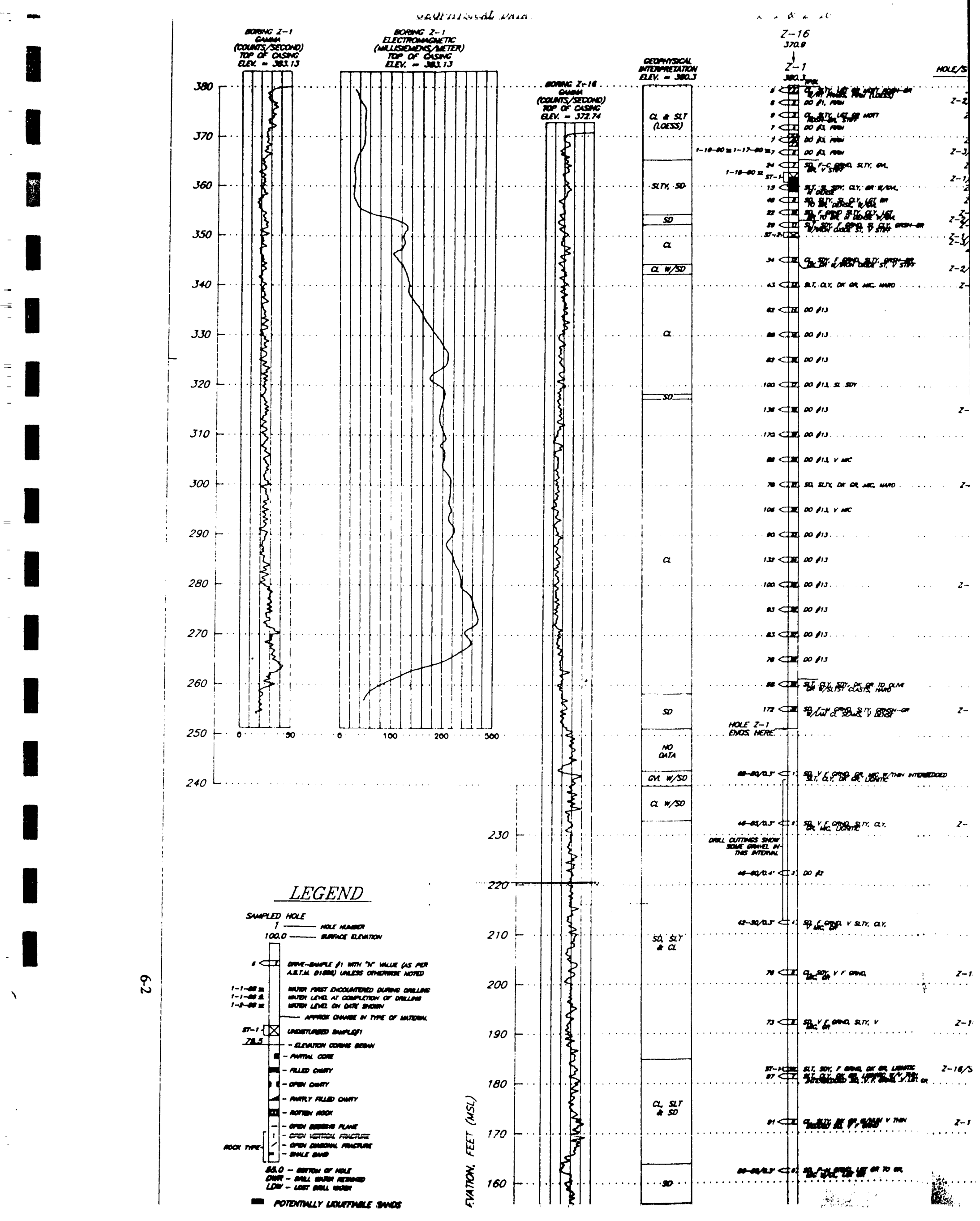




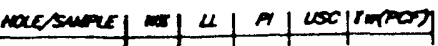

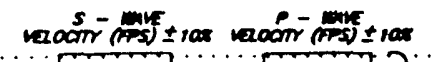

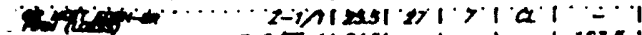
t-2st-1! kns! - ! - ! - ! 1215!

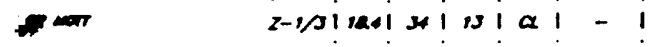

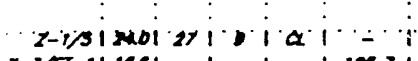
$z-25 T-1 \mid$ 1ed $-1-1-123>1$

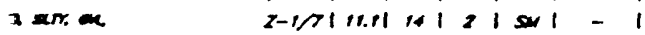

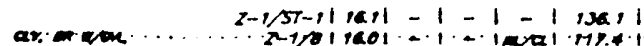
Z-10!127! - ! - ! sa ! iseo! encher.

Pr. 5 sis and

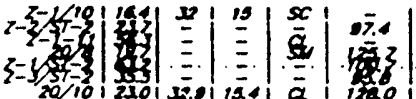

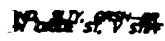
z-2st-Jisesi - i - i - i ars i

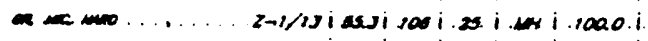
$z-1 / 10$ isasi $20 \mathrm{i}$ 15 i w i a 0 .

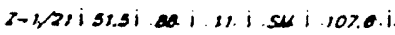
tist ARgen ing 280 $z-1 / 30122.7125$ i Nopisti

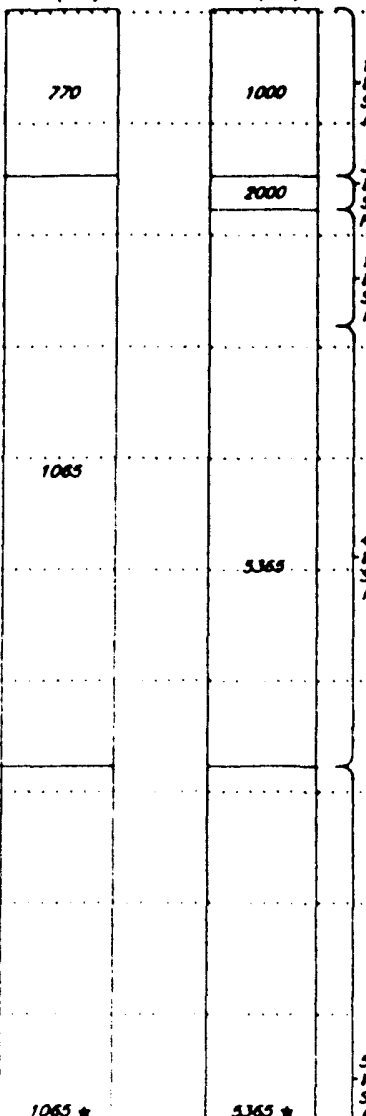

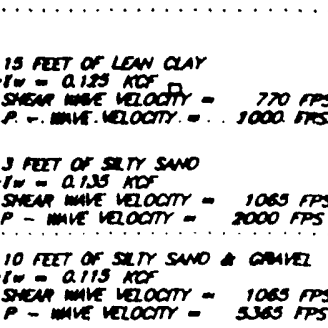
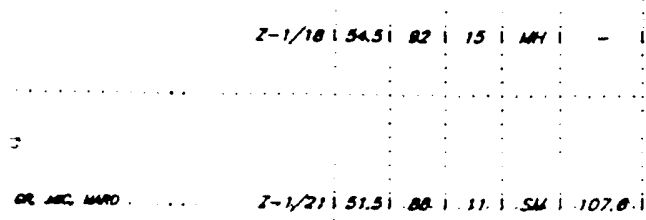

$2-1 / 2315471$ or 1 191 and i

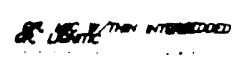

ner.ar.

$\operatorname{mos}$

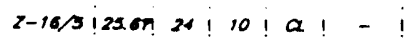

are.

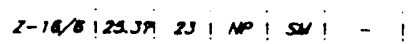

P- mive velocir - subs prs

mocor - ros ros

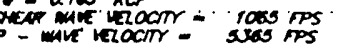

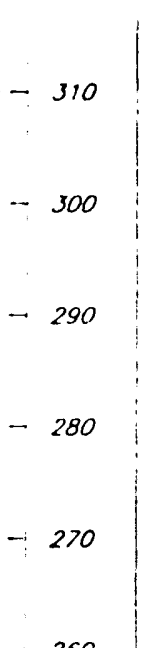

So ret of ser cur a curer S/L

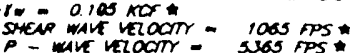

5 sec of ser swo

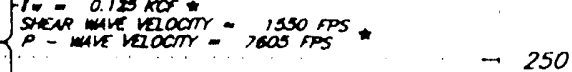

$\therefore 240$

35 reer of mpresdoed swa sur a car

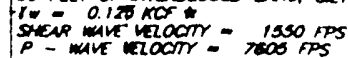




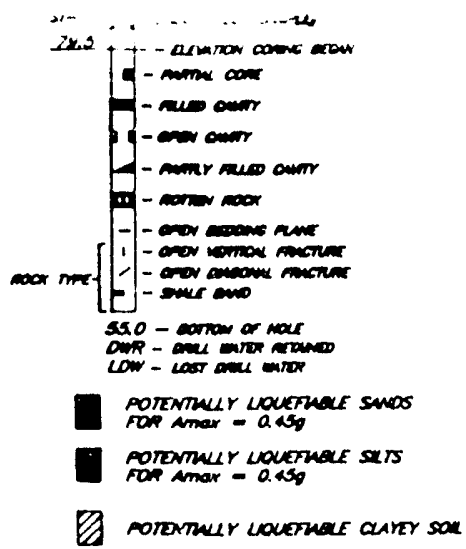

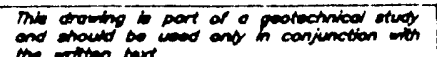

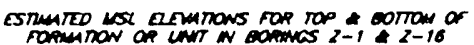

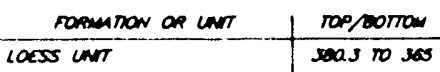

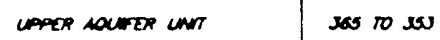
RraOnul Nourer unt ASENT POPTDES Cacex ropuntow 340261

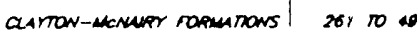

- estimiteo vacue

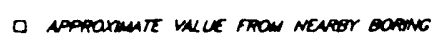

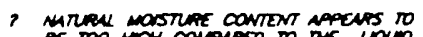

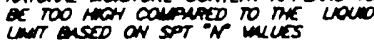

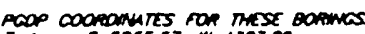

$7-1$ - 5 ses5.57. 2527.80

- data suppued or ERCE 1900

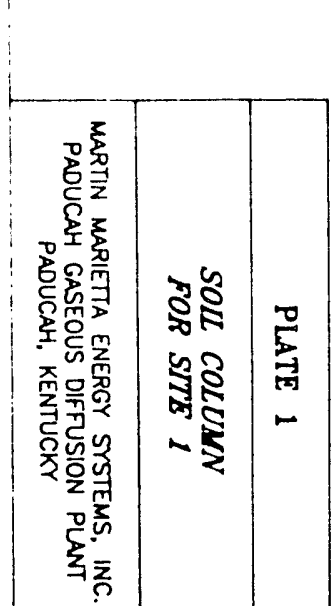

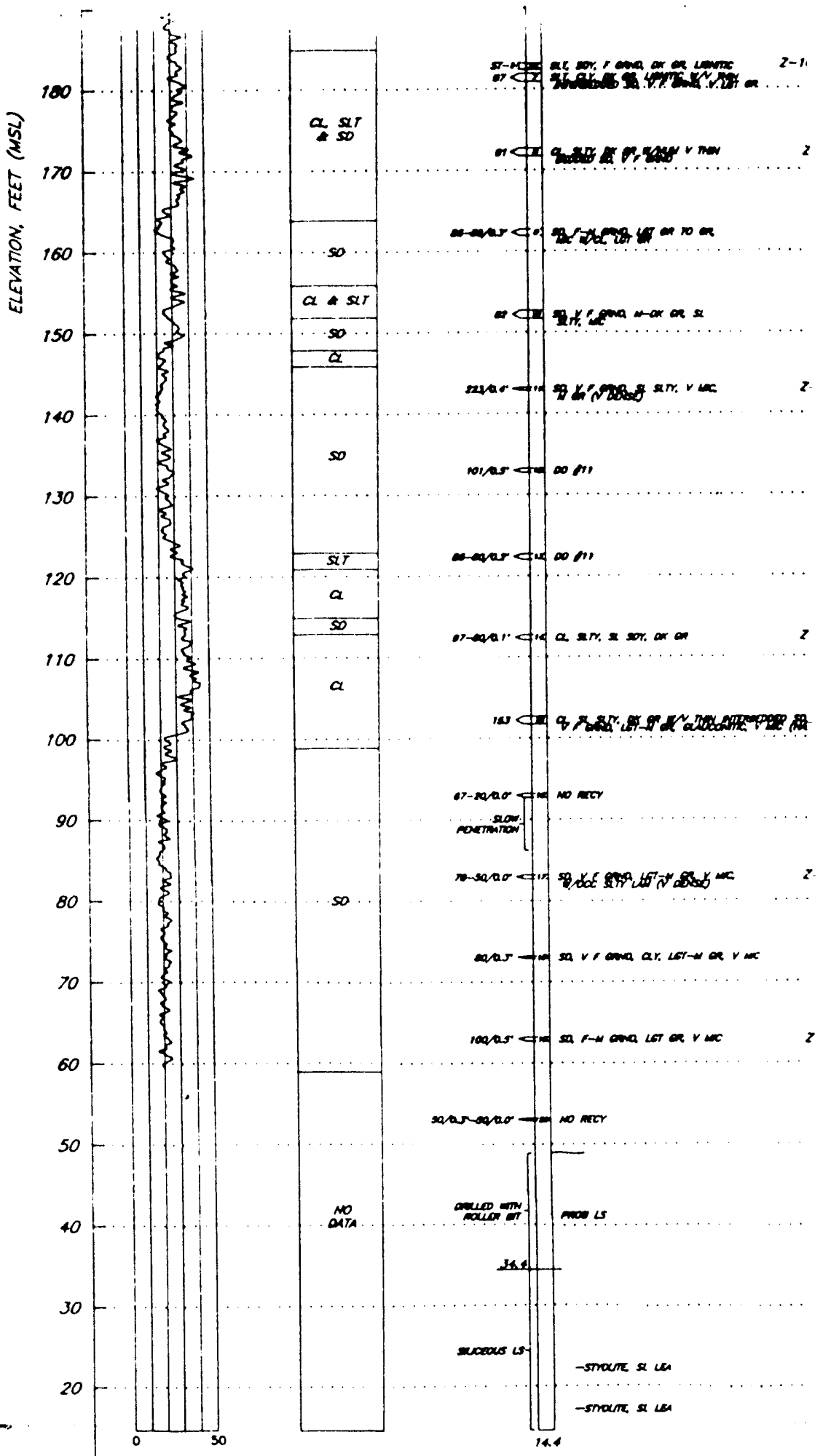




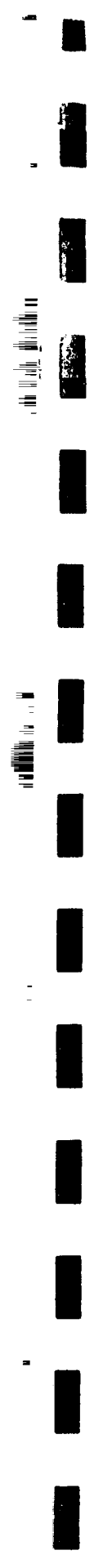

GROPHISICAL DATA

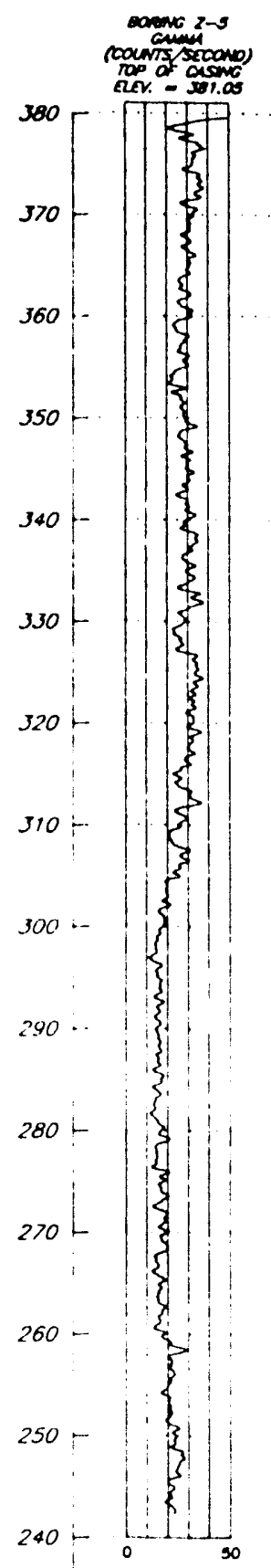

arcinamizacice

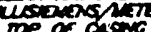

ofr or d di.

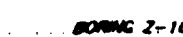

$\cos ^{2+16}$

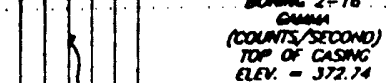

acomisacu

ar. -20

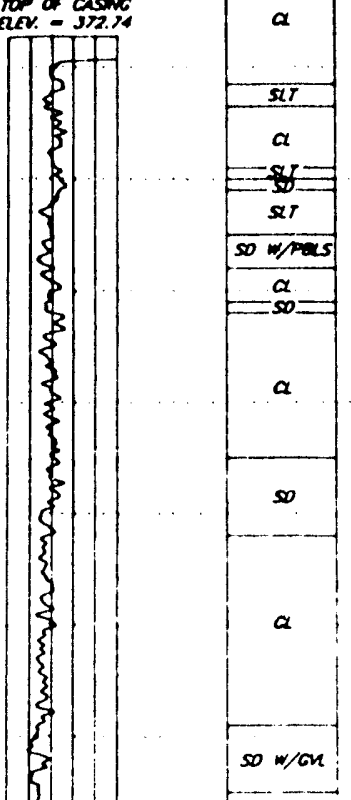

$230 \mathrm{~L}$

w
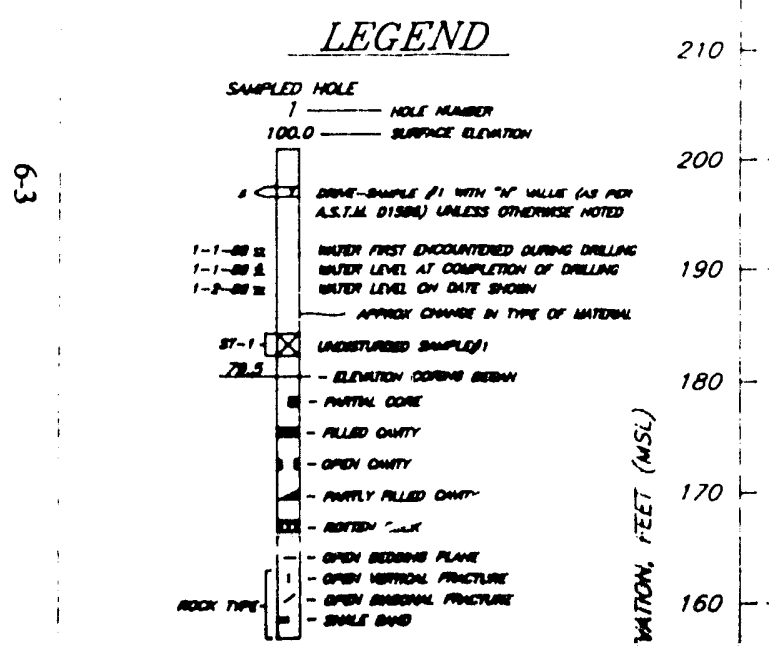

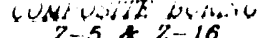

$$
z-16
$$

$3>5$
$z>0$

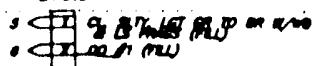

nou

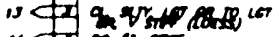

"CP con mir

18 Co a r r sm

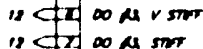

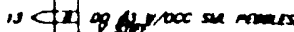

- Ques cor rim

- Ch co as r sm

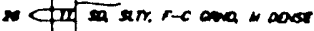

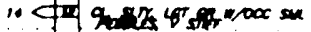

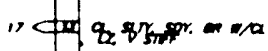

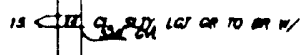

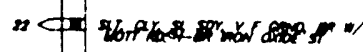

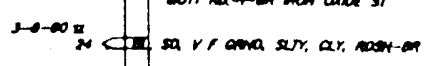

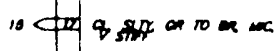

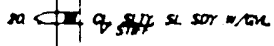

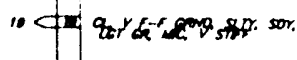

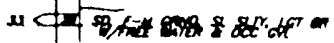

"C Por a

ares. for on $\&$ sor, 1

$0<x$ ar sor recona.

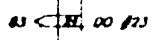

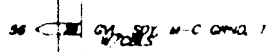

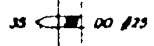

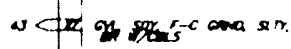

- $4 x, 11$

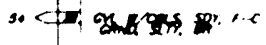

rorty

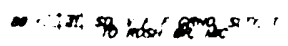

$\infty<+\infty \times \infty$

sor sir

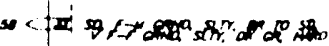

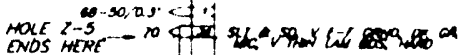
a w/so

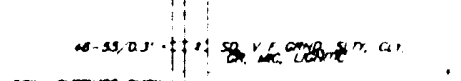

and artmes soon

\section{0}

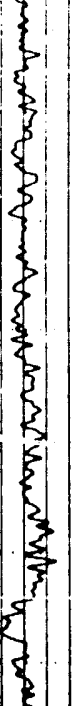




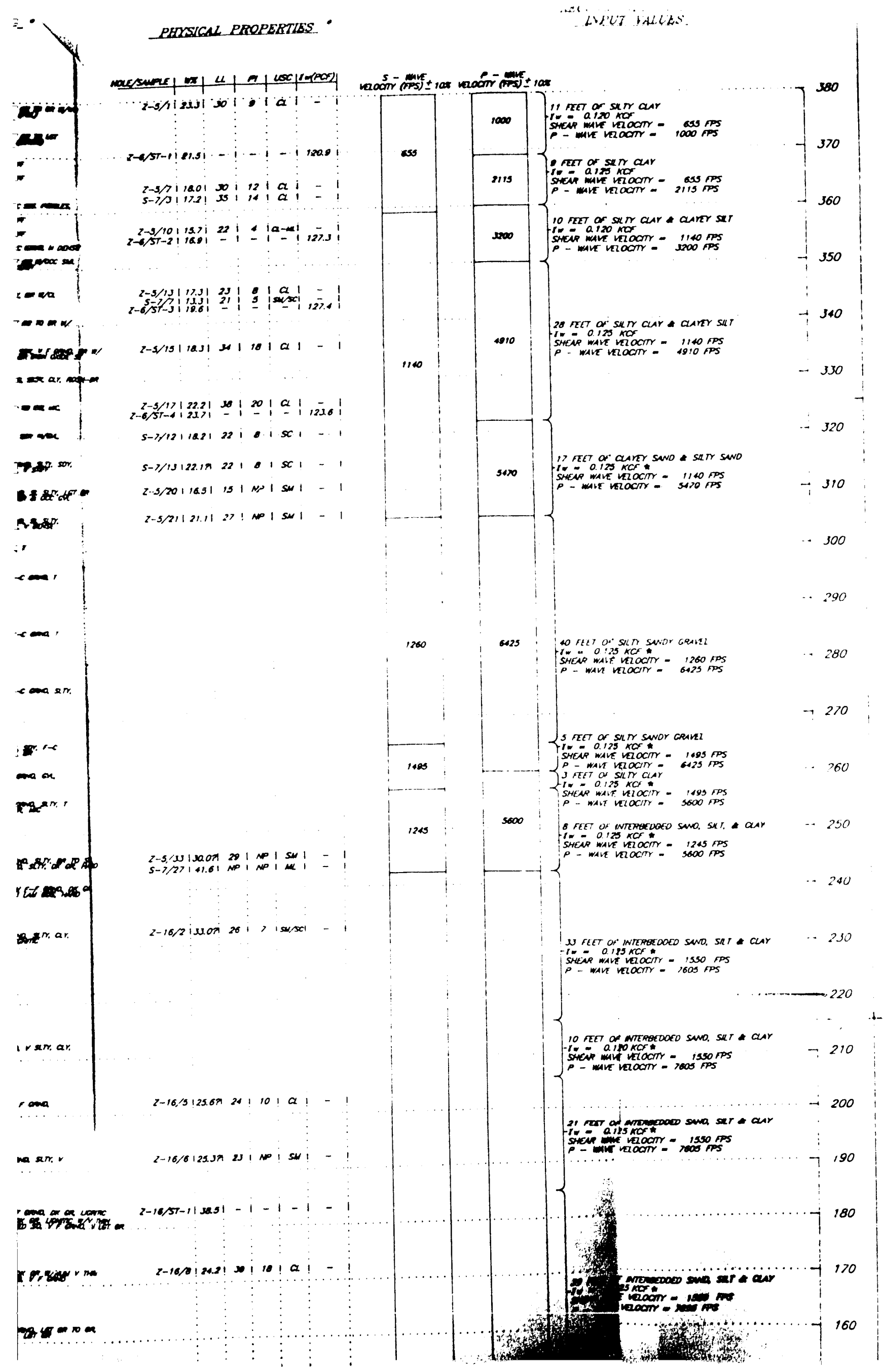




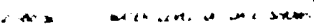
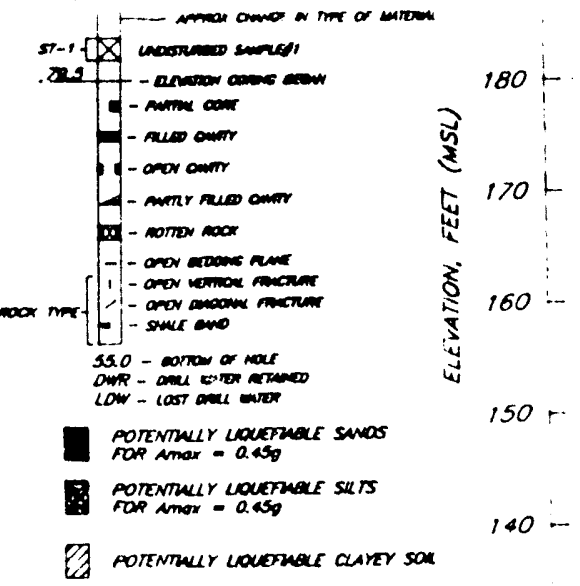

Ba arentiur lowemar charer son

130

$120 \ldots$

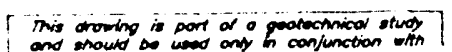

and mound io

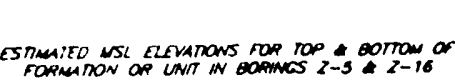

\begin{tabular}{|c|c|}
\hline FOPMATON DR UNAT & rop/soortaw \\
\hline cosss un & 379.90015 \\
\hline UPAER AOUIIEEN UNII & 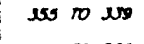 \\
\hline
\end{tabular}

UAOER NOUIIEN UNI

AECOONUL MQUIRER UNT

I" 260

POPTERS CREER FORMMINOW

ABSENT

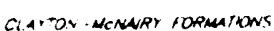

2607049

- estinitio vaue

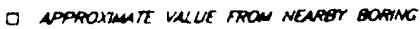

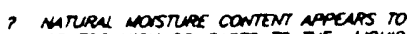
of ThO MAH COMPNED TO THE LOWO

pCop cooponmutes rop nuese bopimas

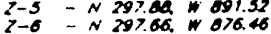

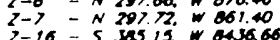

- data suppled ot eacor 1990

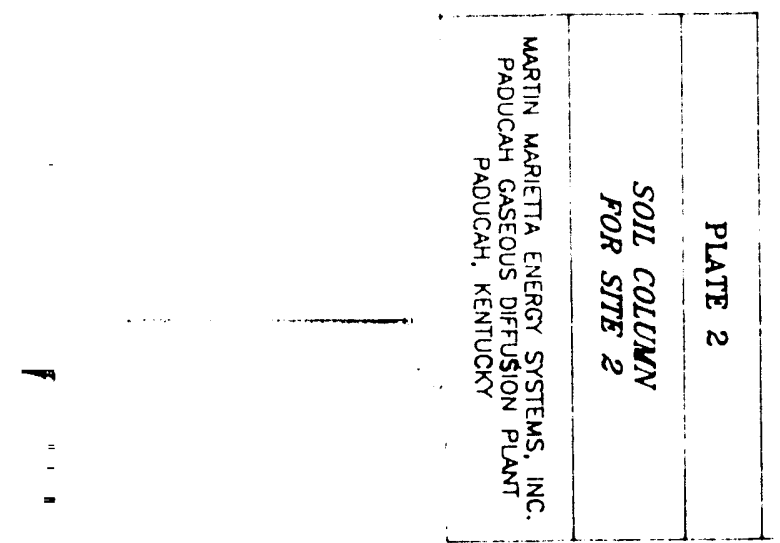

$110-$

100

90

$e^{2}$

g. ...

$\therefore$

$60 L$

so:

5.: :

$\infty$

i

$x$

22

22

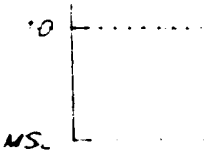

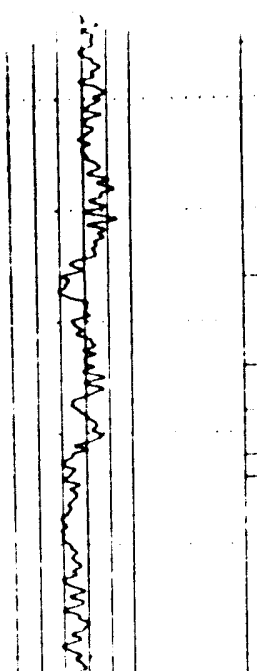

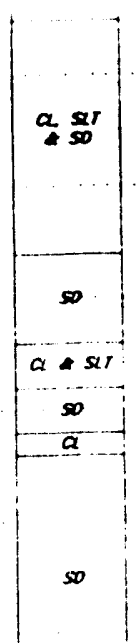

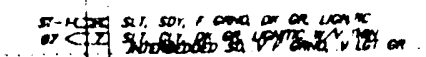

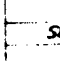

a

so

$a$

$\ldots+\ldots$
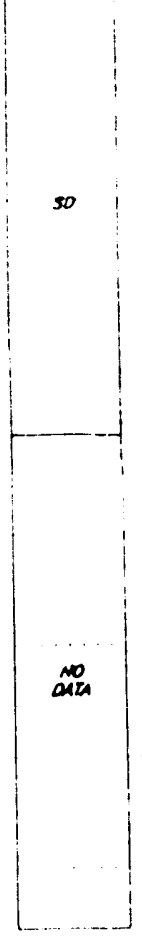

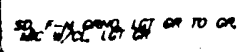
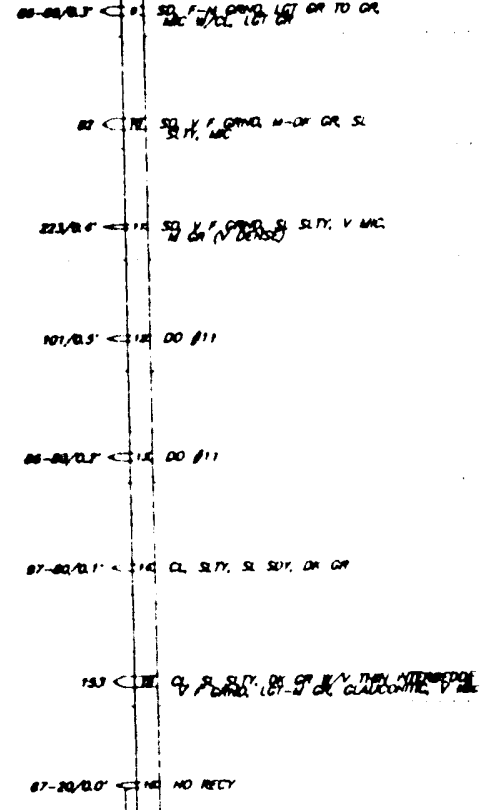

$$
\text { merminiou }
$$

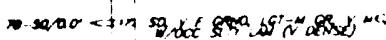

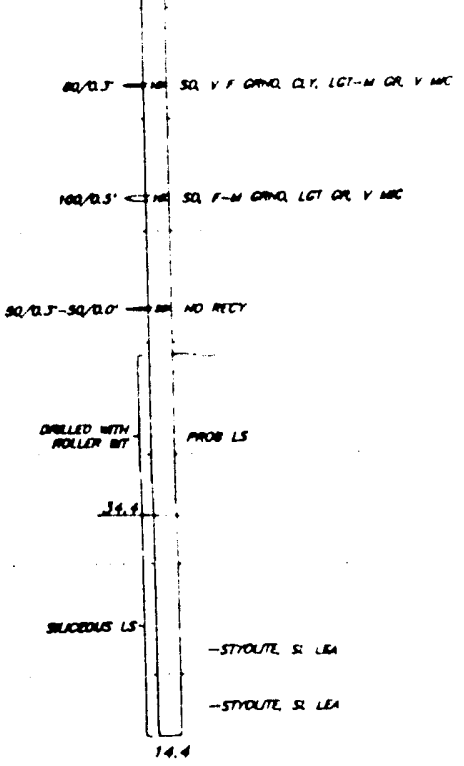



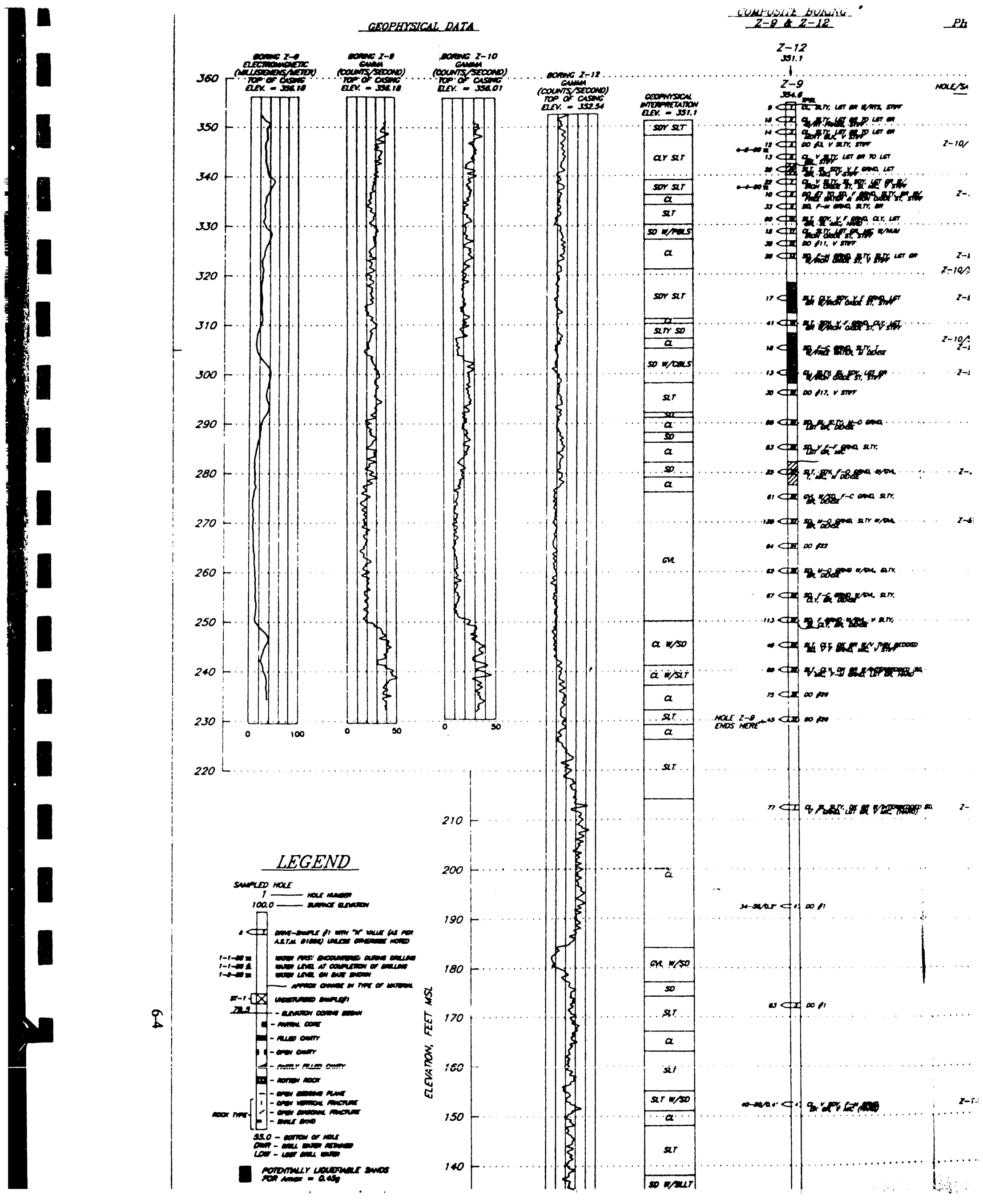


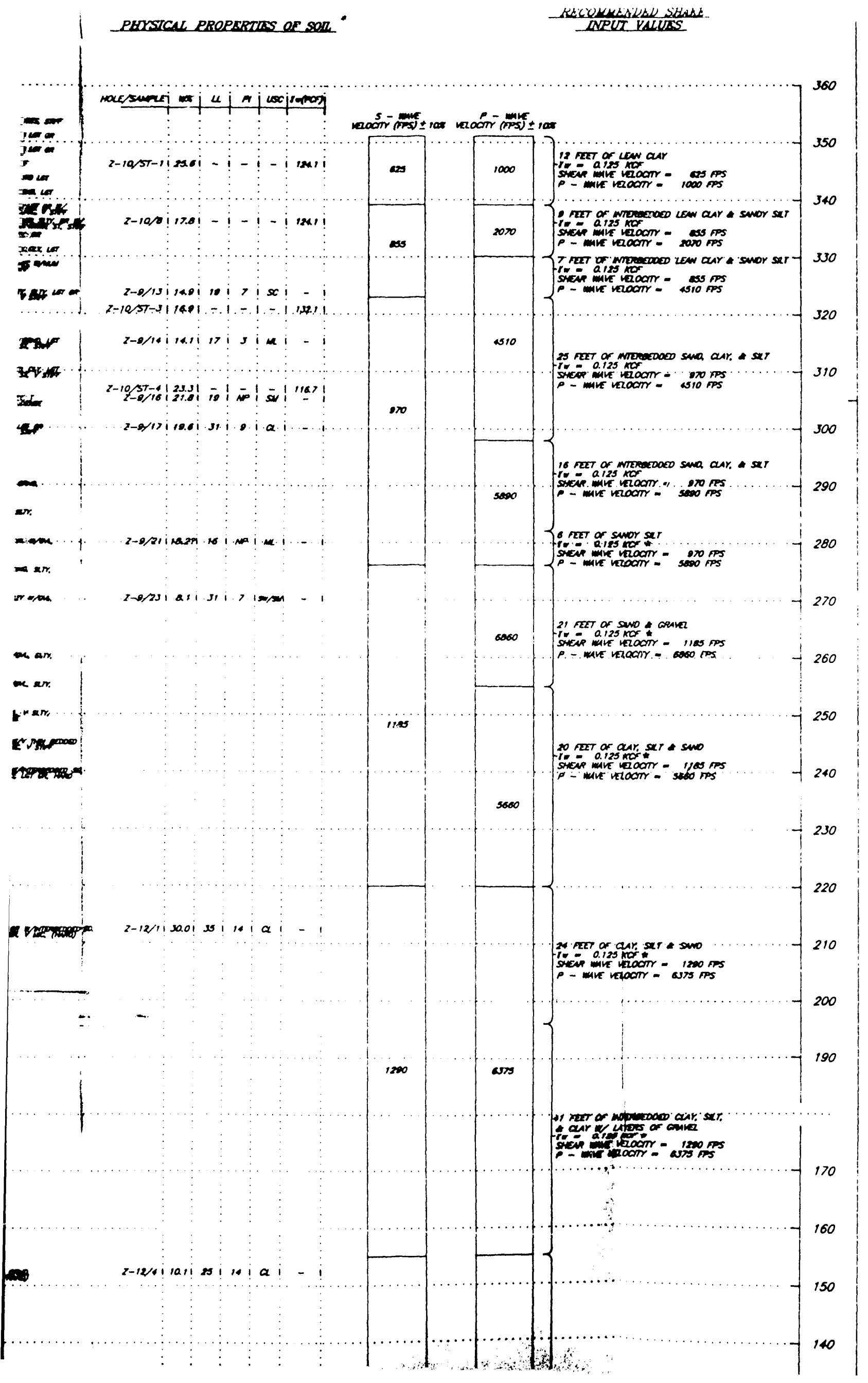




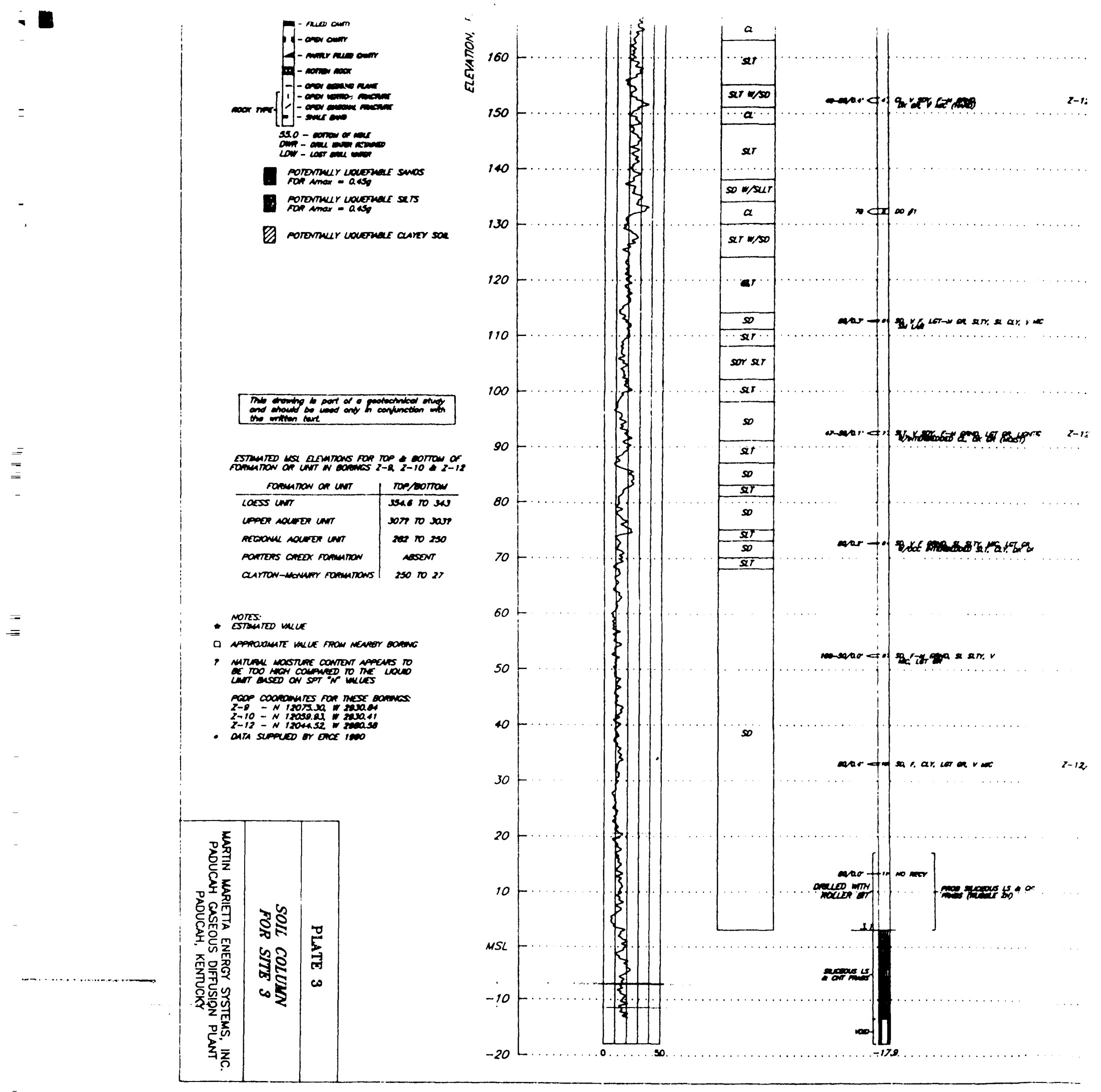




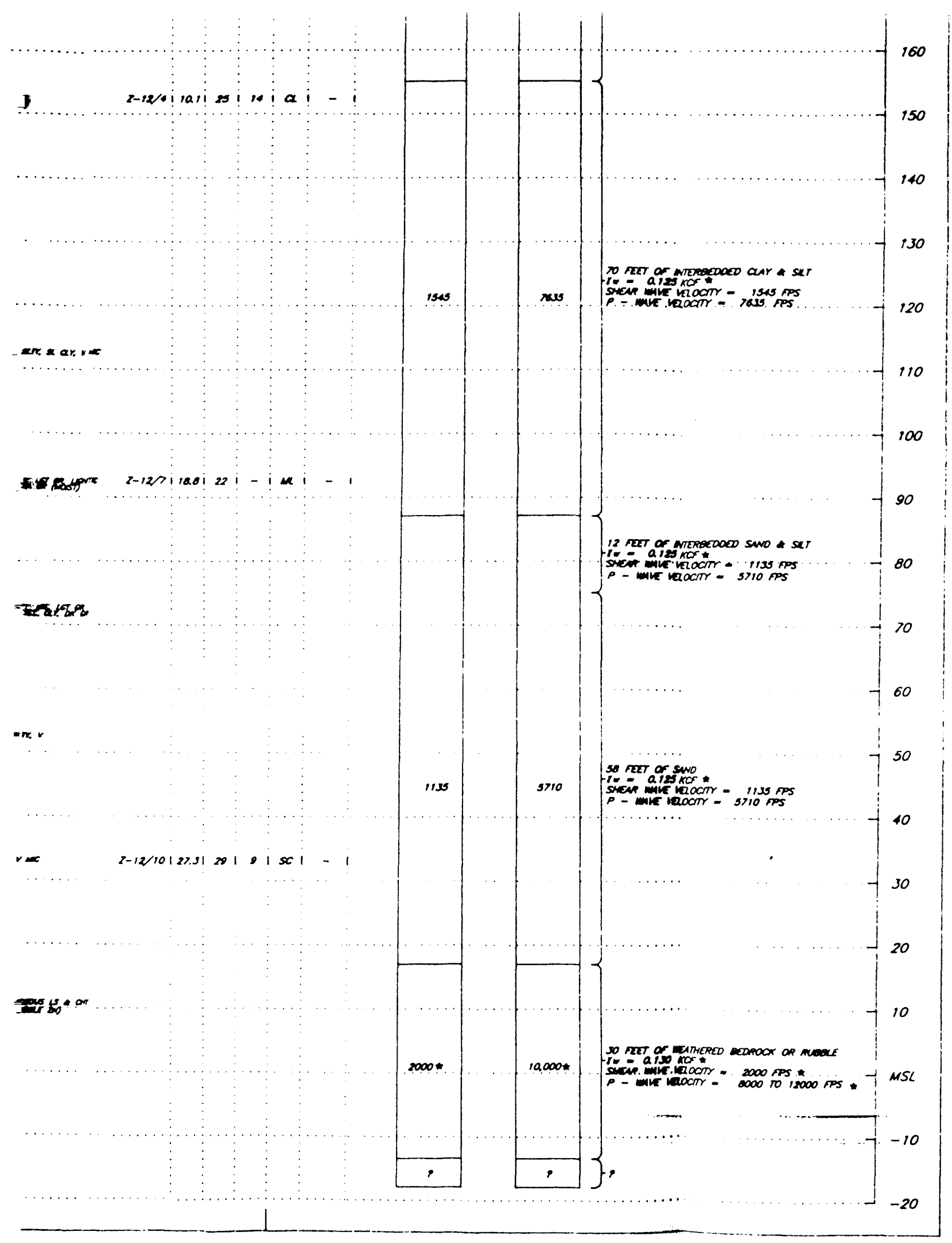




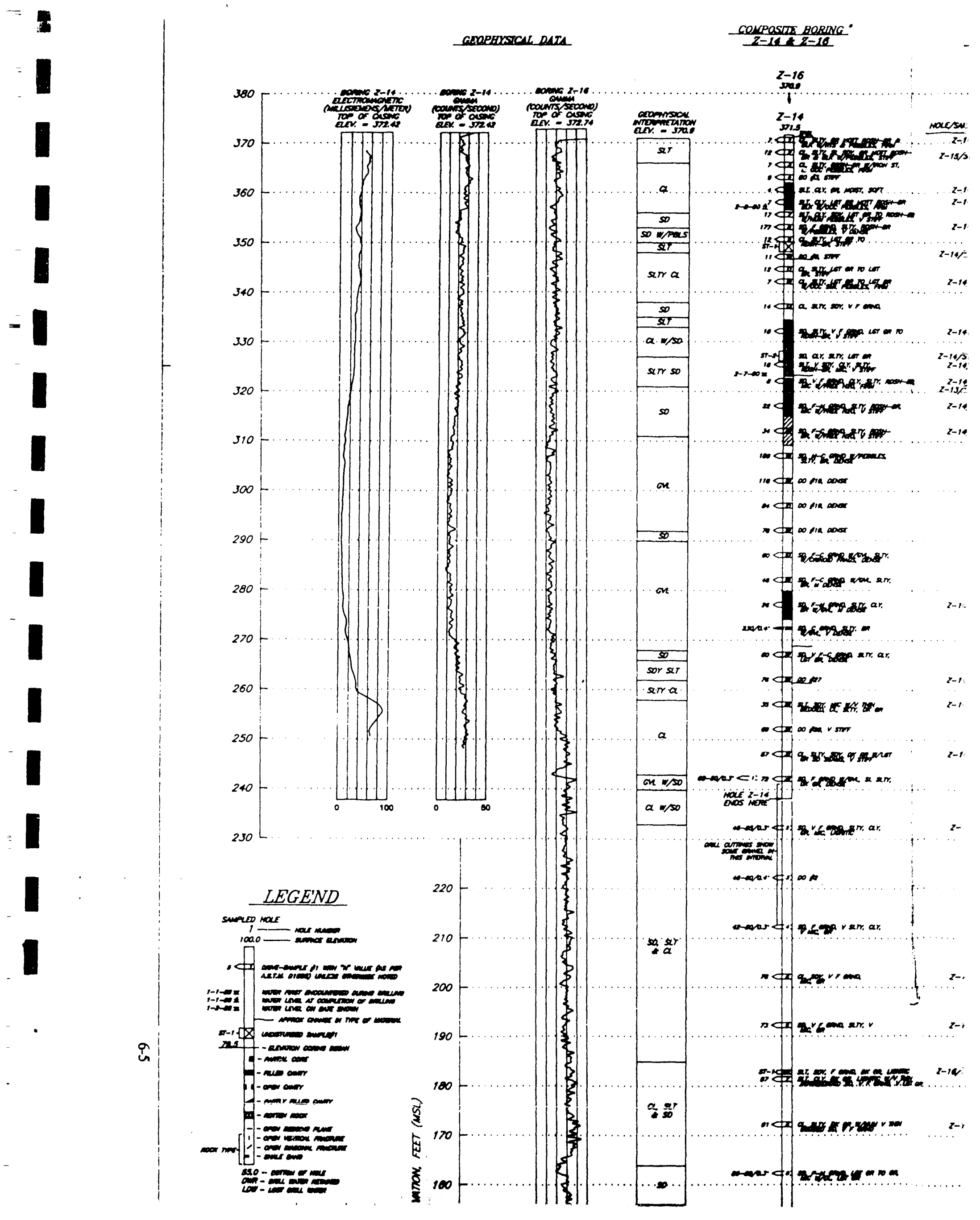




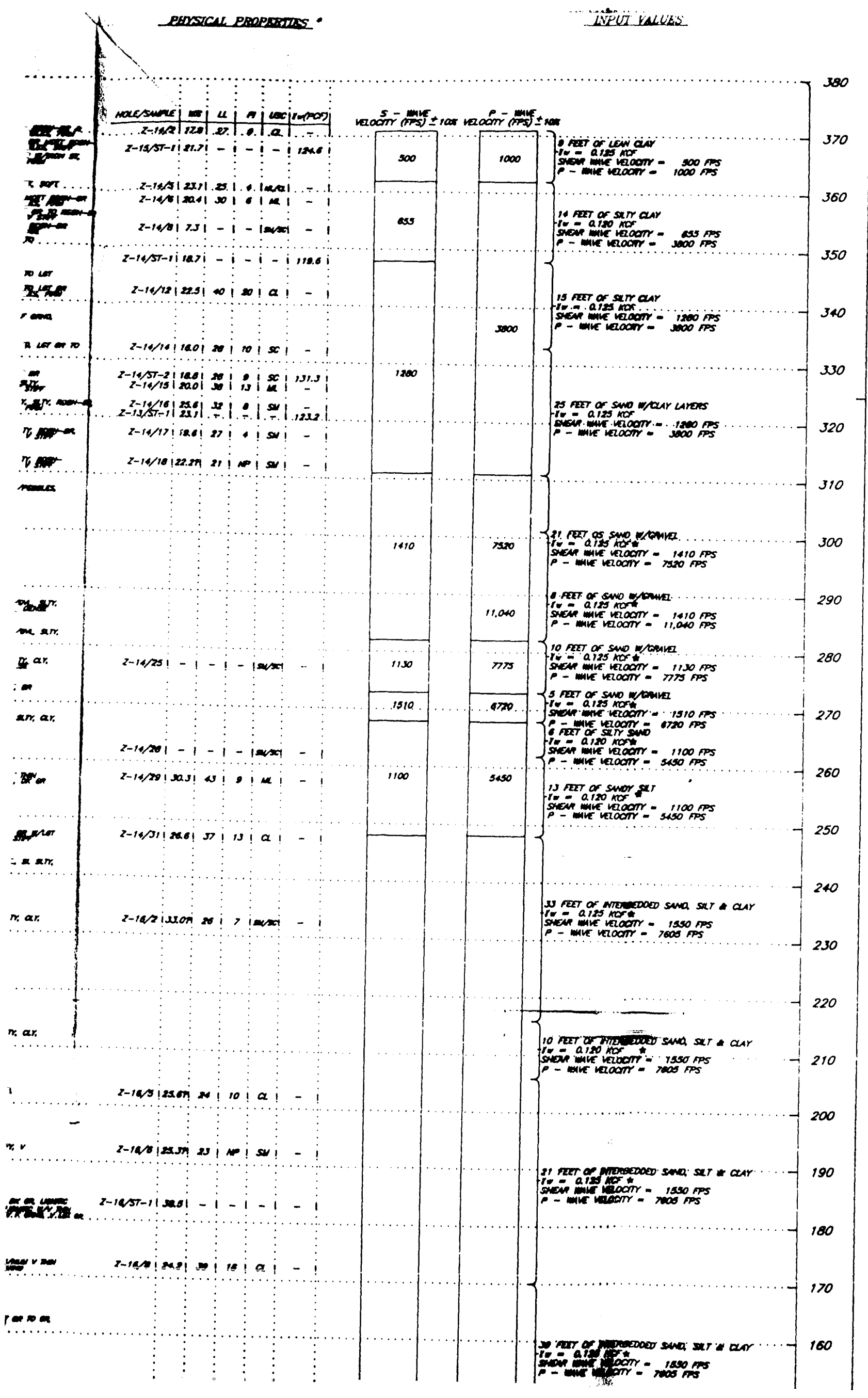




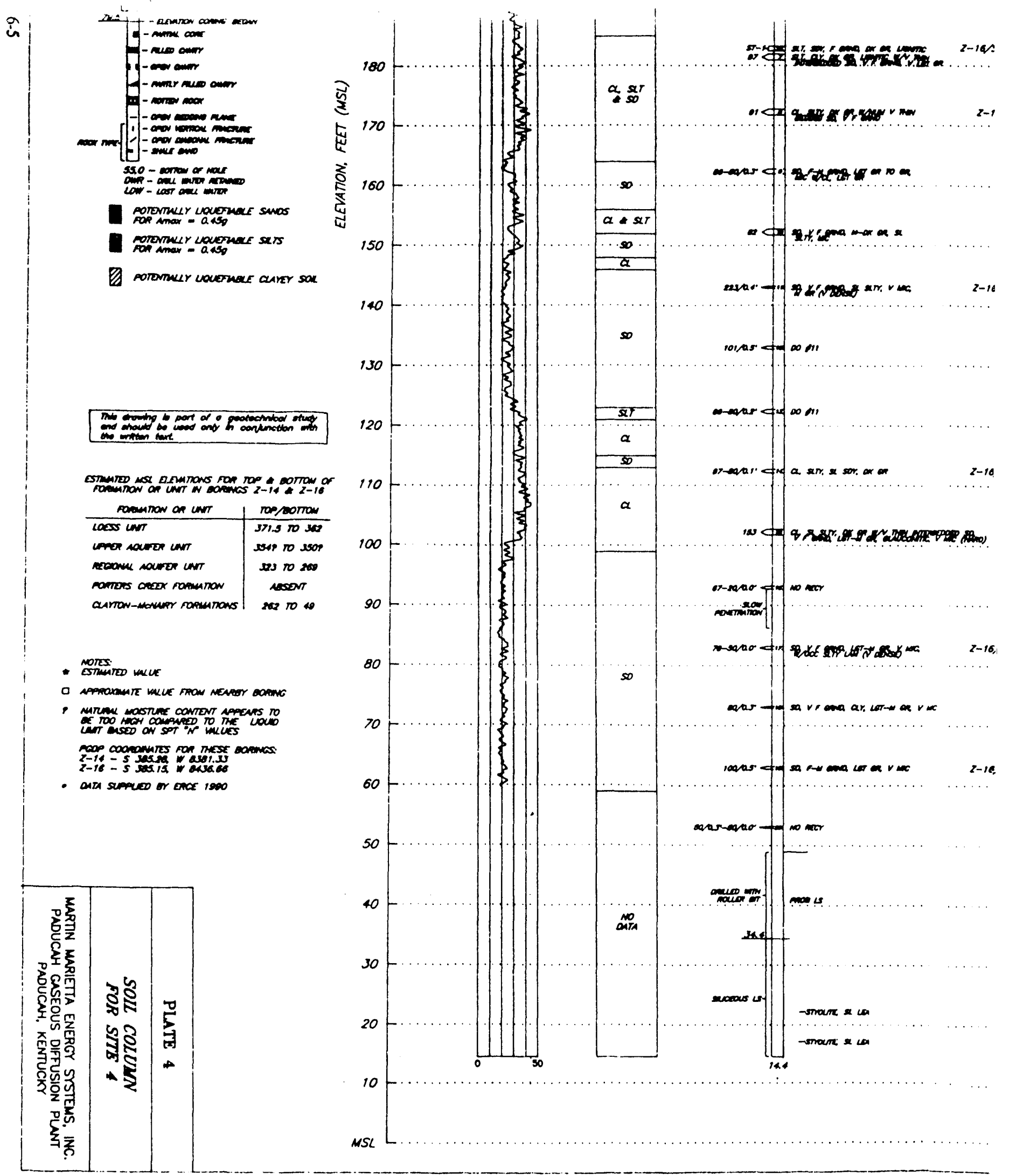




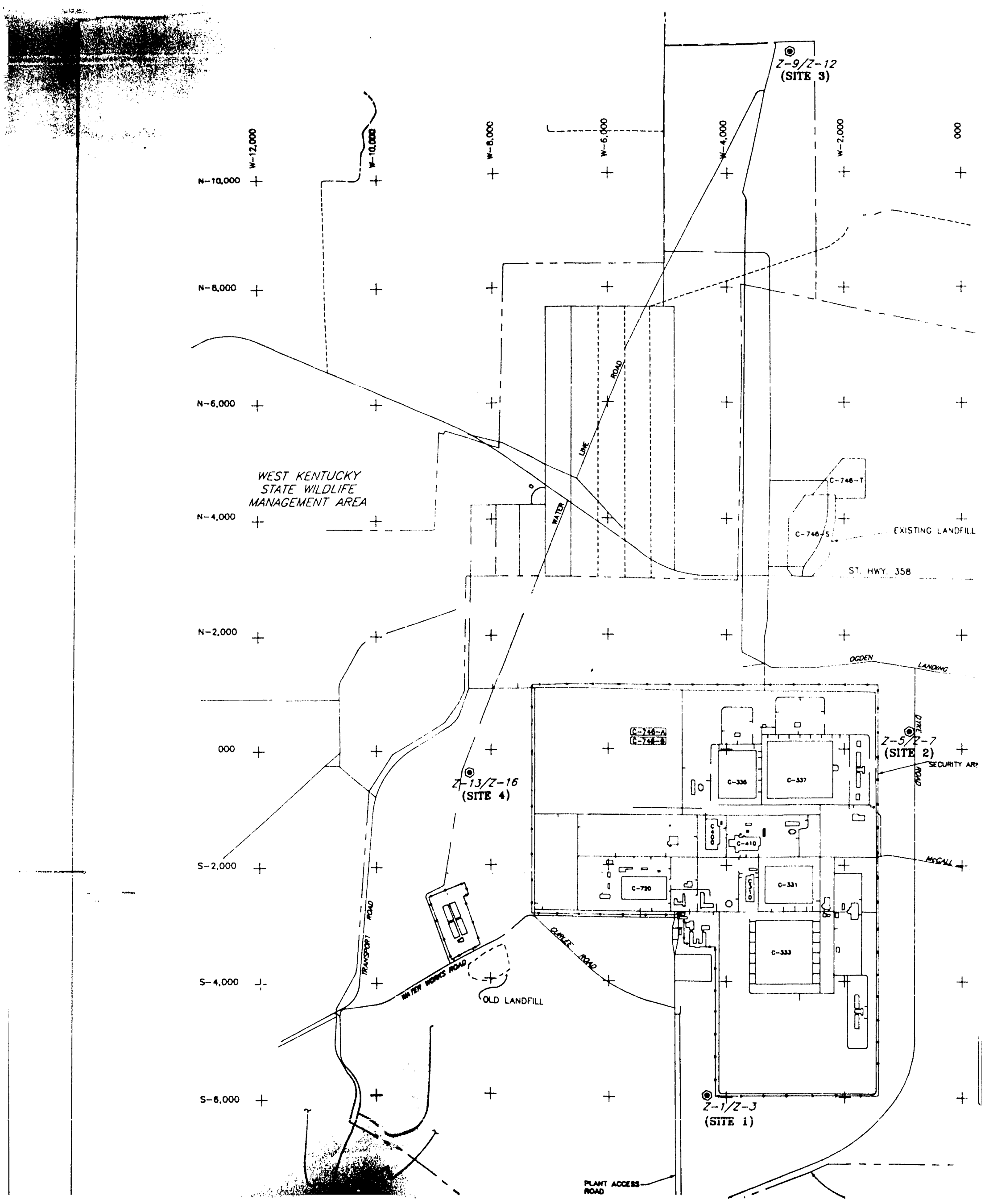




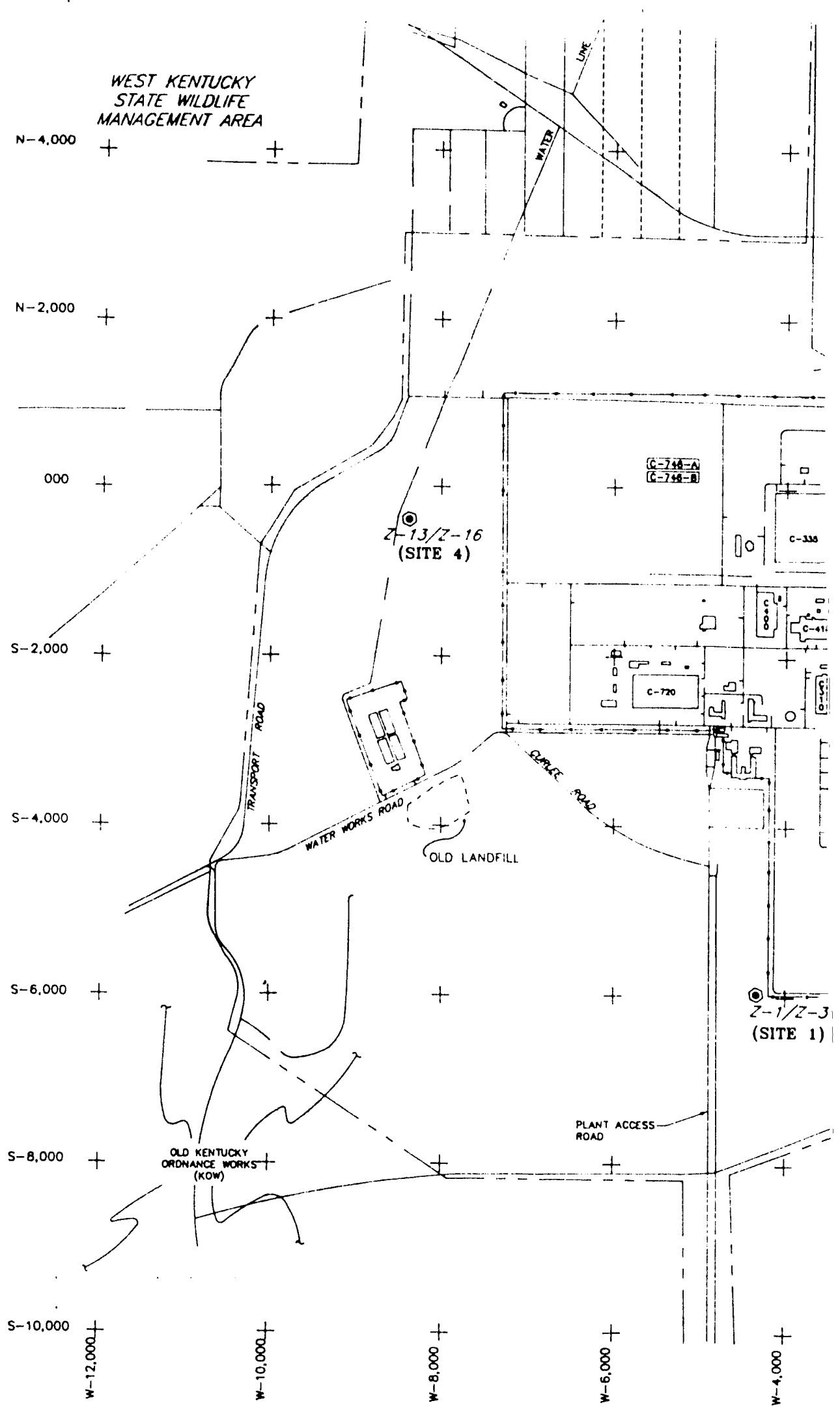




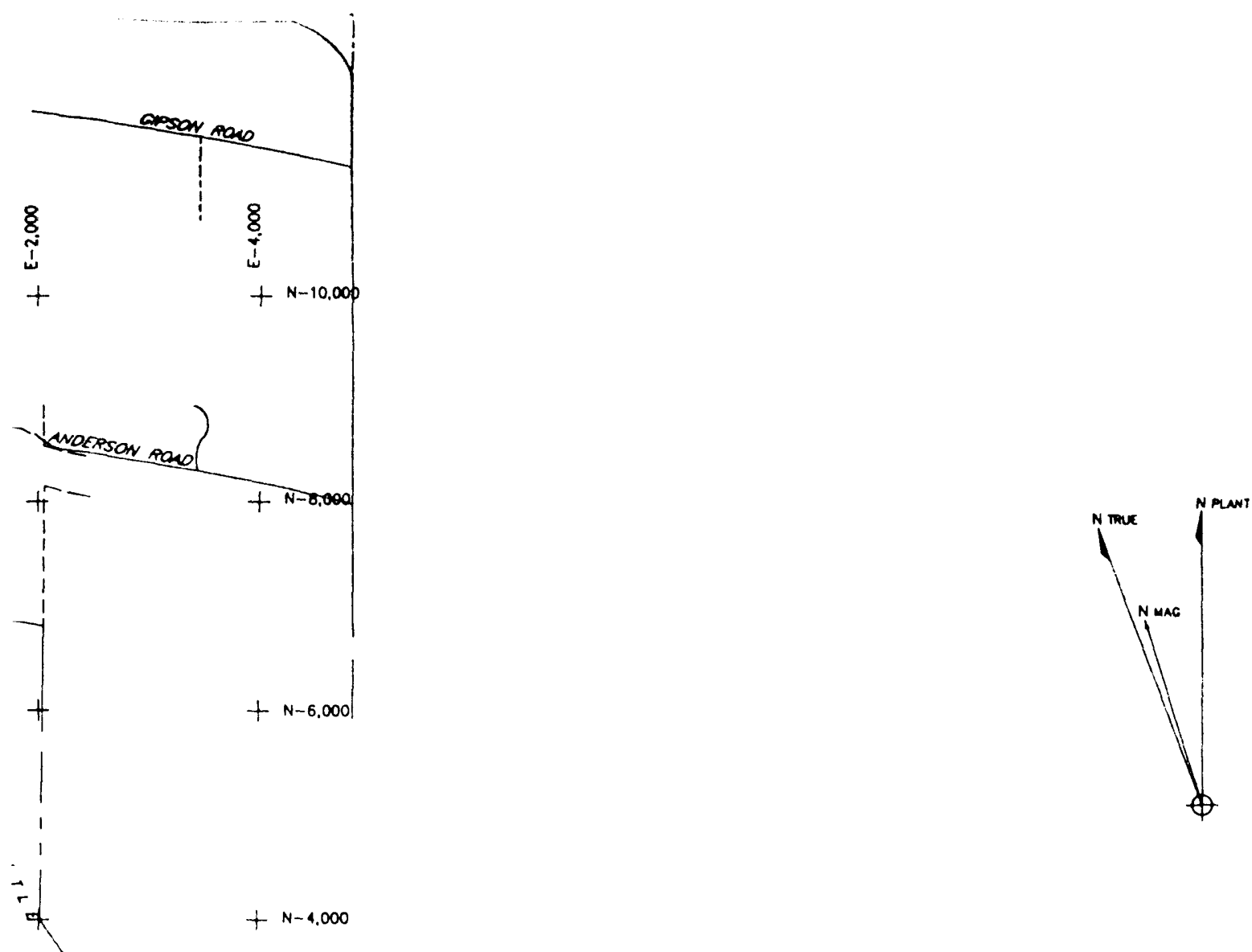

\section{NOTE}

1. THS BASE MAP IS ADAPTEO FROM MUL TPLE DRAMNGS SUPPLIEO OY MARTN MARIETTA ENERGY STSTEMS IN ADOITON TO THE JOPPA OUADARIETIA ENERGY STSTEWS IN ADDITON TO THE FOP OENERAL RCTCERNCE OWLY FOP PRECISE LOCA TON OF FEA TURES REFER TO LARGEP SCALE WAPS ANO/OP FEA UURE COOROIAATES

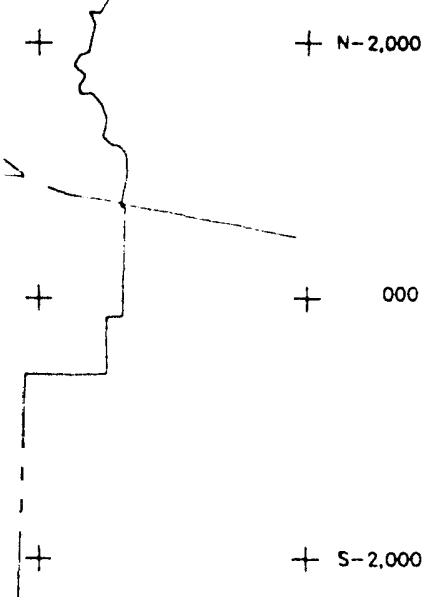

$\underset{z-1 / z-3}{L E G E N D}$

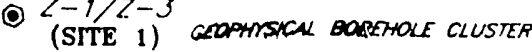

$+5-4,000$

$+\quad+5-6.000$

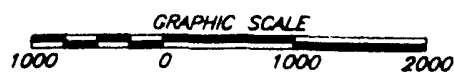




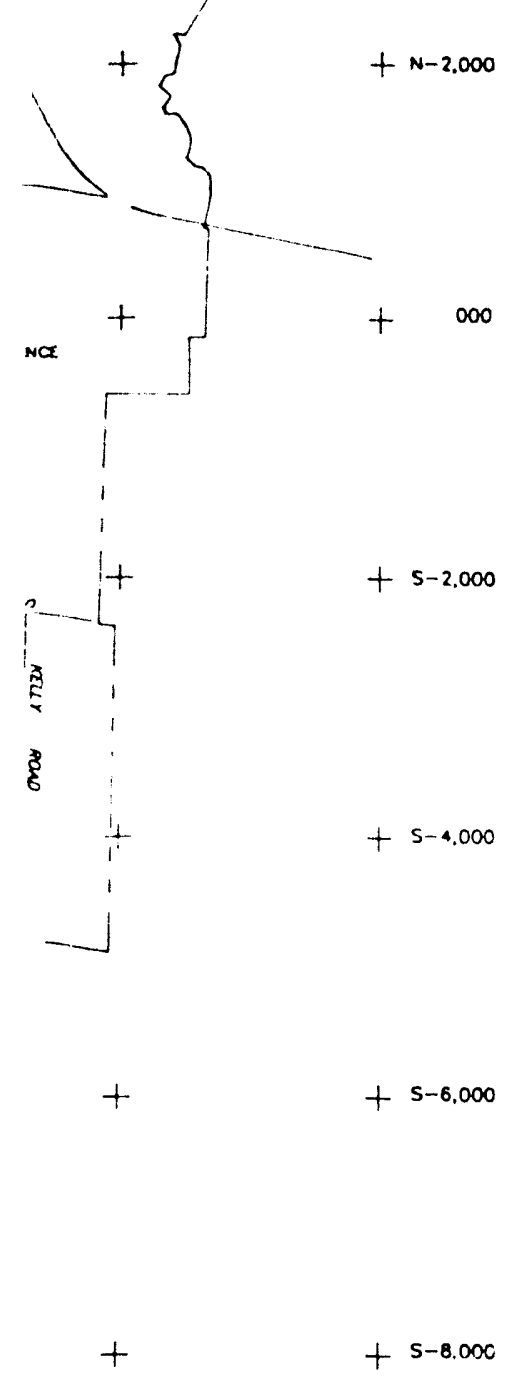
1. THIS GASE MAP IS ADAPTEO FROM MUL TPLE DRA MNGS SUPPLIEO OY MARTIN MARIETTA ENERGY STSTENS IN ADOITON TO THE MOPPA OUADRANGLE AND HEA IH OUADRANGLE (1:24000) PUBLISHEO OY TME US GEOLOGIGAL SURVEY AND IS INTENOED FOR GFNERAL REFERENCE ONI $Y$ FOR PRECISE LOCATON OF FEA UURES FEFIE TO LARGLA SCALE MAPS ANO OR FEATURE CMOPOINATES
$+$
$+5-8.000$

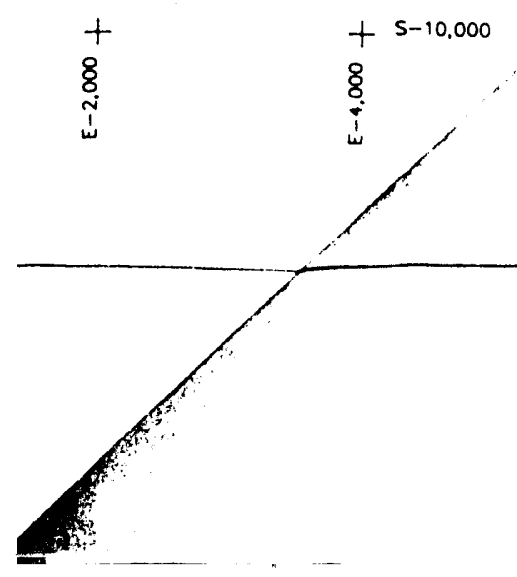

PLATE 5

SITE LOCATION OF GEOPHYSICAL BOREHOLE CLUSTERS

MARTIN MARIETTA ENERGY SYSTEMS, INC. PADUCAH GASEOUS DIFFUSION PLANT PADUCAH, KENTUCKY 


\section{DISTRIBUTION}

Department of Energy - Headquarters

C. A. Caves

J. R. Hill

J. K. Kimball

A. P. Littman

Department of Energy Field Office, Oak Ridge

M. A. Boyd

J. D. Hughlett

J. D. Jackson

J. W. Parks

W. A. Hampton

Martin Marietta Energy Systems, Inc.

T. A. Angelelli

J. E. Beavers

J. M. Bownds

W. R. Brock

W. A. Burnett, PGDP

W. K. Crowley

J. W. Douthitt, PGDP

T. O. Early

P. A. Gourieux , PGDP

R. J. Hunt

R. O. Johnson

V. W. Jones, PGDP

R. A. Just

R. H. Ketelle

M. A. Kuliasha

D. W. Lee

R. R. Lee

W. E. Manrod

D. M. Massey, PGDP

R. R. Miller

R. M. Reed

J. E. Rushton

K. E. Shaffer

R. B. Shelton

W. P. Staub (5)

W. C. Stoddart

J. C. Wang

GDP SAR Document Management Center

GDP SAR Document Management Center-RC

K-25 Site Classification Office (3)

PGDP Library (2) 
Lawrence Livermore National Laboratory

J. G. Harri

Risk Engineering, Inc.

R. K. McGuire

St. Louis University

R. B. Herrmann

U. S. Army Engineer

Waterways Experiment Station

D. W. Sykora

U. S. Geological Survey

S. T. Algermissen

University of Kentucky

R. L. Street

University of Tennessee

R. D. Hatcher 

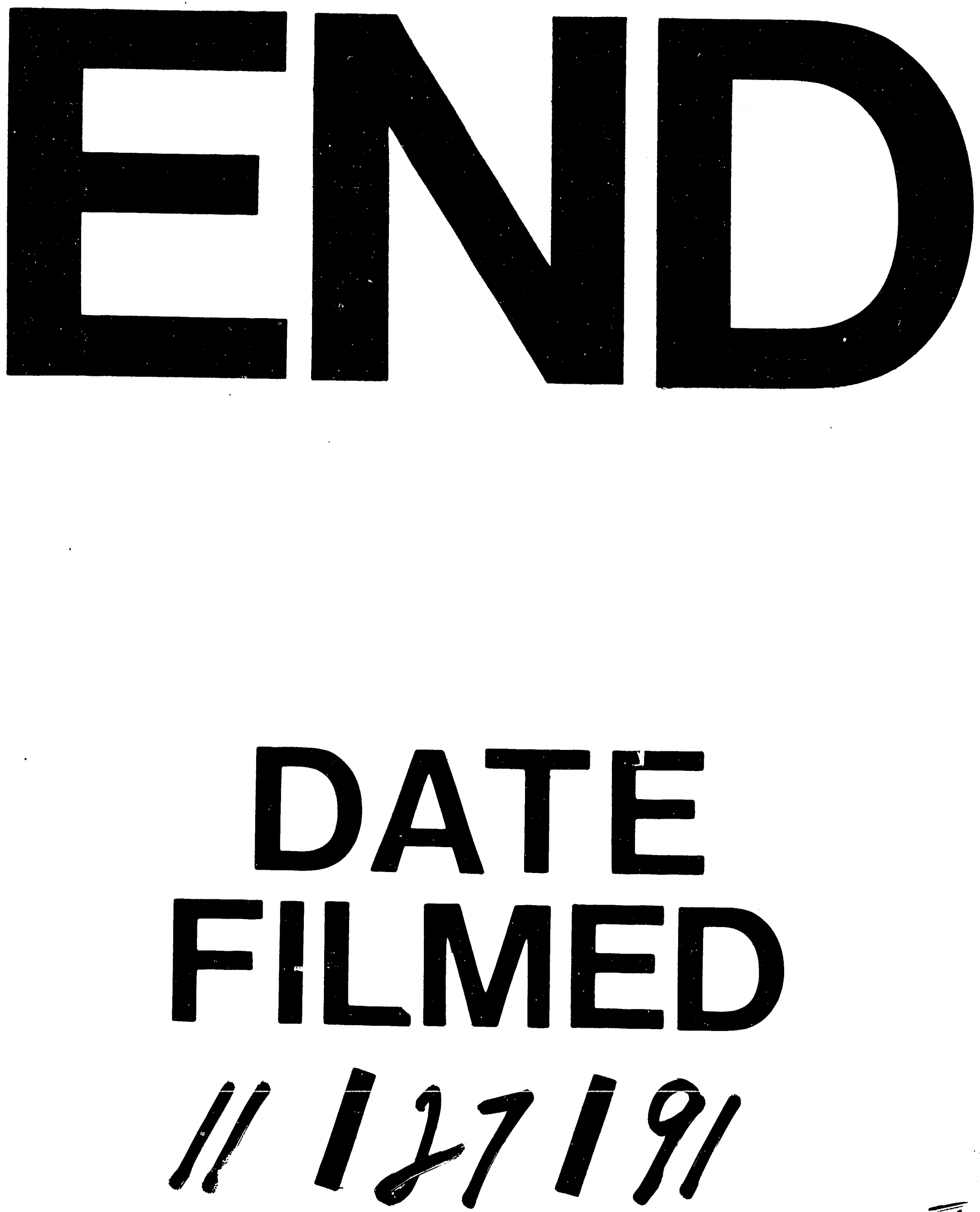
